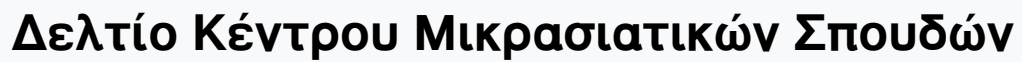

Tóp. 4 (1983)

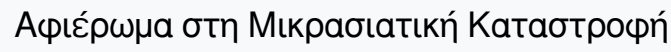

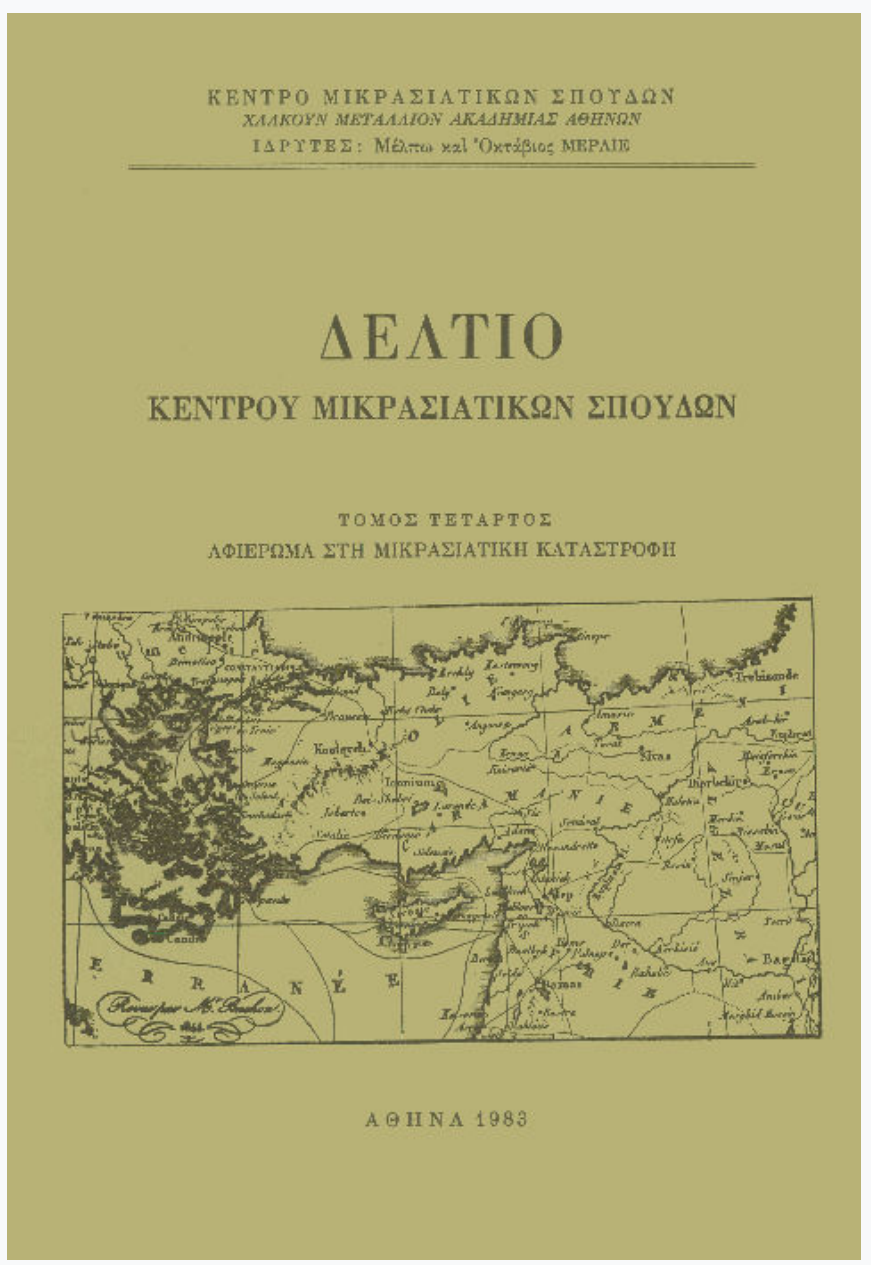

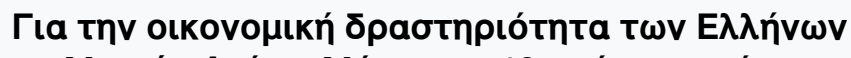

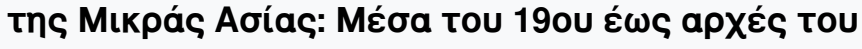
20ou aı́vva

A. J. Panayotopoulos

doi: $10.12681 /$ deltiokms.37

Copyright @ 2015, A. J. Panayotopoulos

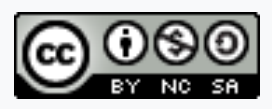

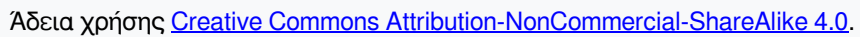

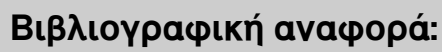

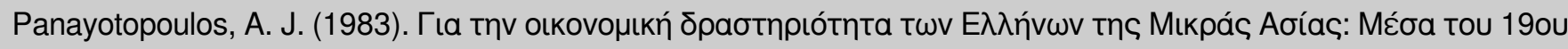

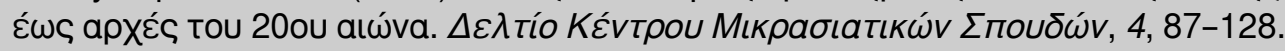

https://doi.org/10.12681/deltiokms.37 


\section{ON THE ECONOMIC ACTIVITIES ON THE ANATOLIAN GREEKS Mid 19th Century to early 20th*}

\section{Introduction}

There has always been, occasione data, much talk about the remarkable prosperity of the Ottoman Greeks in Anatolia. All authors and travellers agree that in the 19th century and the beginning of the 20th, they were the most developed and enterprising element in the Ottoman Empire. But, we should note, there were differences among them which derived from the fact that the Hellenic millet was not a homogeneous entity. Hellenic communities were settled in urban centres, but also always contained a vigorous agrarian element. As fas as their internal structure was concerned, there was undoubtedly a stratification and a broad distinction could be drawn between the substantial merchants and the well-off landowners, the small shop-keepers and those in the liberal professions, and the masses of the poor peasants and urban workers.

All the same, the Hellenic communities were not all developed to the same extent. Their economic condition depended upon their geographical position. Since the Anatolian Greeks were scattered almost everywhere in Anatolia, their situation varied greatly from region to region. However Smyrna, the gâvur Izmir, with its increasing number of Greeks contributed to the widespread view that they constituted "purely a city element» ${ }^{1}$. Smyrna was more than just an important port. The construction of the Aydin and Kassamba railsways connected the fertile hinterland with the coasts, mainly to Smyrna's advantage. Its trade increased and

${ }^{*}$ This paper is based on research undertaken for a doctoral thesis; I would like to thank Manos Charitatos who provided me with the Yearbook and Guide of Smyrna. Thanks are also due to Dr. E. Karakitsos of Imperial College, London, and Dr. A. Kitroeff who were kind enough to discuss the matter with me on numerous occasions.

1. S. Antonopoulos, Mirod' 'A situation commerciale et économique des pays compris dans la circonscription du Consulat général de France, Paris 1892, p. 69; and K. Dieterich, Hellenism in Asia Minor, Engl. trans., London 1918, p. 20. 


\section{A. J. PANAYOTOPOULOS}

so did the Hellenic population, which pushed its way into the interior giving new impetus to agriculture. It should be emphasized that agriculture was the primary occupation of Anatolian Greeks, even in the coastal areas, and only a minority in the cities was engaged in trade and other similar professions. However, the influence of the urban centres was more evident because they all lay on the main railroad lines starting from Smyrna, and going inland in four directions, and from Constantinople. They were collection and distribution centres for both local trade and export-import, since they were connected with Smyrna and Constantinople.

In this paper, our objective is to compile as complete a picture as possible of the economic conditions of the Anatolian Greeks. Nevertheless, we shall have to accept the economic data available with caution, since much of it was distorted from political and nationalistic expediency. Thus, all the information will be taken as indicative of the state of affairs prevailing at the time and not as definitive statements of facts. Conclusions that are easy to reach are just as easy to repudiate.

\section{Hellenic economic expansion}

The proclamation of the Hattı Şerif of Gülhane in November 1839 marked a turning point in the millet policy of the Ottoman Empire: it gave pride of place to Christians in all subsequent dealings between the Empire and the Great Powers. One year earlier, in August 1839, the BaltaLiman trade convention between Britain and the Ottoman Empire had paved the way for the improvement of the living conditions of Christians. That agreement abolished all state monopolies and regulatory activities, as well as the sale of purchasing licenses by the state and the employment of state purchasing agents. These measures, as we shall see further on, inaugurated an era of free-trade. Thereafter, any foreign country which signed treaties with the Empire automatically benefited from the "most favoured nation clause». The economic consequences of the Treaty were remarkable for both British and other foreign traders, as well as for the Hellenic element ${ }^{2}$. Anatolian Greeks were mainly established in the coastal areas. Free-trade brought them into closer contact with European states with whose markets they then established

2. See M. Todorova, «British and Russian policy towards the Reform Movement in the Ottoman Empire", in Études Balkaniques, 1977/3, p. 20, 23, 24; also O. Köymen, "The advent and concequences of free trade in the Ottoman Empire - 19th century", op. cit., 1971/2, p. 49. 
relations. Making use of commercial concessions granted to foreigners, the Ottoman Greeks managed to make a better living than their Muslim compatriots. And soon, they tended to supplant the Muslim element on the littoral and gradually won the upper hand in certain regions of the interior by gaining control of every commercial activity.

Their economic ascent was not only helped by the promulgation of the Hatt Serif and the abolition of state monopolies, but also by the Christians' exemption from the army. The Muslims, handicapped by the long military service, fell into the hands of usurious money-lenders (usually Ottoman Greeks or Armenians), whereas the Ottoman Greeks, excluded as they were from positions of political power, tended to concentrate all their activity on commerce and the liberal professions. Business contacts and opportunities provided by their co-religionists abroad helped them to strengthen their position in the economy of the Ottoman Empire. Furthermore, the existence of the Greek State increased the ethnic awareness of Ottoman Greeks settled in the coastal areas and led them to behave in a clannish manner, which was never allowed however to endanger their economic interests. Their clannish behaviour can be witnessed to by the flood of immigrants from Greece herself and from the neighbouring islands of Mitylene, Chios, Samos and Rhodes, who strengthened the Hellenic presence in Western Anatolia ${ }^{3}$. W. M. Ramsay remarked that the Oriental element (the Muslims) was not in retreat as a result of open war, but that «it dies out on the coast by a slow yet sure decay ${ }^{4}$.

That silent transformation on the coastal regions was observed by several travellers. In the first quarter of the 19th century, Muslims dominated Christians numerically and economically. Fifty years later Muslims had been pushed to the upper valley of the Meandrus river (Büyük Menderes), where they lived from agriculture and animal husbandry. In a zone, which extended several miles inland from the seashore, Ottoman Greeks steadily established their dominance. The advance of the railroad was followed by that of the Ottoman Greek.

The construction of the railroads, a result and at the same time a a cause of a shift in trade routes, started on 22 September 1856. Despite

3. Dieterich, p. 41; also, C. Issawi, «The transformation of the economic position of the Millets in the nineteenth century», in Christians and Jews in the Ottoman Empire; The functioning of a plurul society, eds B. Braude and B. Lewis, vol. I, p. 261-285;

4. W. M. Ramsay, The Historical Geography of Asia Minor, London 1890, p. 25; also Ramsay, Impressions of Turkey, during twelse years' spanderings, London 1897, p. 130. 


\section{A. J. PANAYOTOPOULOS}

the unfavourable terms for the Ottoman state of the respective concessions, the railways gave an impetus to agriculture and trade. The Aydin Railsway and the Kassamba Railsway both started working in 1866, one year before the promulgation of the law on immovable property ${ }^{5}$. The former traversed $515 \mathrm{~km}$ of the valley of the Meandrus river, while the latter stretched for $263 \mathrm{~km}$ through the valleys of the Hermus (Gediz Chay) as far as Alașehir (Philadelphia). Later on, the railroads were extended towards the southeast. It was not only in the fields of trade and agriculture that the Hellenic element benefited from the railway. Large numbers of railway personnel were either immigrant Greeks, experienced in the maintenance of tracks on the railways of the Peloponnese and Piraeus, employed as workers in the workshops and directors of the companies, or Ottoman Greeks, like the station-masters ${ }^{6}$. "As the railkways goes inland», wrote Ramsay, «the Greek element goes with it and even in front of $i t$ ).

All towns through which the railway passed were in the hands of the Greeks. And so was the land. In the valley of the Kaystrus river (Küçük Menderes) in Theira (Tire), Odemis, Bayindir, the Greeks, although few in number, were reported to possess almost all the land. Despite the poor transport system, the brigandage and the lack of public security, the bad administration and the intricate legislation on land ownership, the Ottoman Greek peasant started to cultivate all the fertile valleys of Western Anatolia. It should also be mentioned that several wealthy Greek families attempted arround 1870 the exploitation of the valley of the Hermus river. Their task, however, was not accomplished systematically because the Kassamba railsway had not yet been extended that far. In the Meandrus river, particularly in its upper valley, the Muslim still resisted. But in general the Muslim peasant looked helpless and improvident? The Ottoman state did not seem to care or it was unable to do anything to help him.

5. See below, the section on agriculture.

6. Antonopoulos, op. cit., p. 42-3; according to Antonopoulos, who was Greece's Consul-General in Smyrna at the turn of the century, the station-masters were the pioneers of civilization in the Anatolian hinterland.

7. Impressions of an anonymous German traveller in Kleio, No. 1123 of 25/6

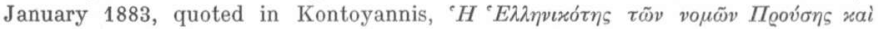

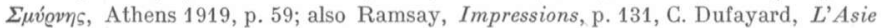
Mineure et l'Hellénisme, Paris 1919, p. 44, and Antonopoulos p. 22-3; also R. Fitzner, Anatolien, Berlin 1903, quoted in Kontoyiannis, p. 50, and Stark, Nach dem Grie-

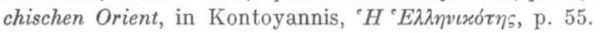


It is particularly German writers who have tried to explain the Hellenic development. R. Fitzner noted that the superior condition of the Greek peasants could be explained by the fact that they were employed in the cultivation of more specialised produce which, though more risky, was undoubtedly more profitable. This included the cultivation of vines, olives, figs, sericulture, etc. ${ }^{8}$

O. Benndorf and G. Niemann attributed that development to another procedure linked with money-lending by millers. In Lycia and Karya almost all millers were Greeks.

"The miller's profession is very profitable, because he is not only paid in cash, but he is also in a position to withhold as much wheat as he spants. The Greek millers are the financiers of the Turkish peasants. They gradually become rich landowners, because the Turkish debtors are not solvent. Afterwards, they invite their relatives to the country, and in that way reinforced, they form small communities... which, if the circumstances are the same will change the whole character of Anatolia» ${ }^{9}$.

The grocer was another pioneer of the Hellenic enterprising spirit. He could replace the miller, wherever the latter could not reach.

«In every small town a Greek grocer is established», wrote another German traveller, "mainly selling 'masticha' drink, which is not prohibited by the Koran, to the Muslims. After ten years the grocer becomes the money-lender to the small town. Meanwhile, new Greek enterpreneurs arrive. Loans multiply on mortgaged Turkish properties by the newcomers... Whenever the Turk return the debts, the Greeks do not accept them. When charged, they bribe the Kadi, and so the Turk has to pay even for legal expenses. When the debt increases, the Greeks become landowners by foreclosing the mortgaged property》 ${ }^{10}$.

A similarly explicit image of that procedure is given by M. Mavrochalyvidis, an Anatolian Greek, in a book on his native town of Axos (Hasaköy). According to him, the 1830's witnessed serious social and

8. Op. cit., p. 50 .

9. O. Benndorf, G. Niemann, Reisen in Lykien und Karien, in Kontoyannis, p. 52.

10. Gelzer, Geistliches und Weltliches aus dem Türkisch - Griechischen Orient, quoted in Kontoyannis, p. 59-62. G. Mavrochalyvidis, Axos, Athens 1957, mimeographed copy in the Archive of the "Centre for Asia Minor Studies", No $68 \alpha \beta / 59 \alpha \beta$. 
economic changes which were not apparent from the very beginning. The skilled Greek craftsman, who was wandering around the country selling his skills, started to sell goods by retail as well.

"Afterwards he settled in the most profitable-looking place. He preferred to sell on credit and to be paid in kind. In that way the Greek retailer was stealing the ignorant and naive Turkish peasant in the weighing out... Thus he earned three times: first, when he sold the goods on credit, second, when he weighed the crops of the Turkish debtor with which he was to be paid, and third, when he resold the (rops $\rangle^{\Perp 1}$.

Mavrochalyvidis maintains that the Turks were honest debtors, because, according to the Holy Law, the Muslim who died in debt was sinful. And his debt had to be honoured by his heirs. The Greek bakkal or grocer or retailer, who earned enough either invested in land or moved to bigger urban centres. This re-distribution of wealth had an influence on social status also.

"Traders supplanted landowners. . they became the new aristocracy. . . Agriculture was gradually considered as a rude occupations ${ }^{12}$.

Another method that he Greeks used in order to make greater profits was that of «stepping in after the harvest, buying the Turkish peasants' crops and conveying them to the towns» ${ }^{13}$. They bought the crops either as agents of the Greek big merchants or for their own profit. In the latter case, however, they were also faced with the Greek big merchants' profiteering.

11. Ibid., p. 93; Compare also with Ramsay, Impressions, p. 131: «It is a point of honour with (the Turk) to make a great show at marriage. He borrows money usually to make a display at some ceremony, to buy a substitute in the conscription, or to give in bribery to an official: then his ruin is speedy, and the land on whose security he has borrosped passes out of his possession». The tendency towards extravagance caused also higher demand for imports. A decree of 1827 addressed to the people of Yenişehir ordered that they should live a more moderate life; see $\mathrm{O}$. Köymen, op. cit., p. 47.

12. Mavrochalyvidis, op. cit., p. 95.

13. A. J. Sussnitzki, «Zur Gliederung Wierschaftslicher Arbeit nach Nationalitäten in der Türkei», in The Economic History of the Middle East, ed. by C. Issawi, Chicago, 1966, p. 114-25; also Rougon, p. 142. 


\section{Agriculture}

Anatolia was an agrarian region and the majority of the population, Christian and Muslim, earned its living mainly by the barter of agricultural produce and meridional fruit and vegetables. Cultivation, which was unsystematic, was undertaken with traditional tools and left unexploited large expanses of arable land ${ }^{14}$. In the Aydin vilayet, the yearly sale of modern ploughs during the two first decades of the 20th century was approximately 4,000 most of which were imported from Greece and bought primarily by Greeks. They used them either on their own farms or for eultivating rented land. But there were only 29 threshing machines in the whole vilayet of which 15 belonged to Greeks, 9 to Turks and 5 to Europeans ${ }^{15}$. In contrast, in the cotton-growing vilayet of Adana, where large landholdings were the norm shared mostly by Greeks, Armenians and Syrians, there was an increased use of more productive methods of cultivation. No fewer than 1,000 mowing machines were in operation, 100 steam-driven threshers, 25 double steam ploughs and 85 ordinary steam ploughs. Taking into account the expanse of arable land and its potential fertility, we must conclude that the use of machinery in agriculture before the 1 st World War was very limited ${ }^{16}$.

Another aspect of agriculture in Anatolia were the different preferences in cultivation of Turks and Greeks, distinctions testified to by numerous travellers and scholars. The Turks, for instance, were mainly occupied with cereal planting and small-scale gardening, and avoided those catch-crops* which were most sought after by Europe. As a consequence they made little or no profit at all.

«Only slowly can they break away from their old established habit of planting only what is needed for their own consumption... And they accustom themselves only with difficulty to a mode of work which implies continuous stooping and are, therefore, aserse to root crops and plants that need hoeing. ... ${ }^{17}$

On the other hand, the Greeks tended to cultivate whatever was more

*Quick growing crop, grown between rows of other crops.

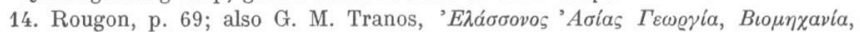

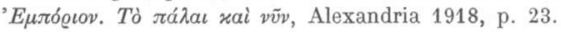

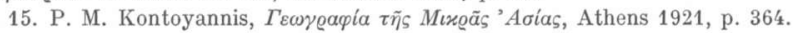

16. A. D. Novichev, "The development of commodity-money and Capitalistic relations in agriculture" (of Anatolia), p. 65-70, in Issawi, op cit.

17. Sussnitzki, op. cit. 
profitable. Cash crops and fruit, vegetables and tobacco, as well as sericulture were preferred to cereal-farming.

However, this millet specialization in agriculture is merely descriptive. It does not explain why there existed such a distinction, which nevertheless was not absolute. In Western Anatolia, for instance, where the majority of the Greeks lived, cereal-farming was mostly in their hands. One reason for this specialization may be attributed to the existence of numerous Hellenic communities along the Western coast of Asia Minor, where the climate permitted the cultivation of meridional produce. Another essential reason, which also influenced the numerical increase of the Hellenic millet, was the specific economic status that the millet enjoyed within the Ottoman Empire. In the first place as we have already noted, the exemption of the Christians from military service, not in itself a strictly economic factor, did essentially help them in their economic activity. On the other hand, the obligation to serve in the army became a dramatic impediment for the Muslims, which seriously affected their morale. They relinquished all hope of improvement and sank even further into apathy. Moreover, the fact that Muslim women played only a minor role made the shortage of labour more acute and aggravated the lot of Muslim farmers already half-ruined under the métayage system ${ }^{18}$. Secondly, Greek landowners being as they were in constant contact with the Greek city-merchants involved in the import-export trade, enjoyed access to the markets of Europe and so geared their efforts to cultivating produce with a high profit margin destined to be shipped out of the port of Smyrna.

The development of specialized produce acted against the spread of share-cropping. The use of better machinery and fertilizers, and a more intensive combating of pests became necessary as was also the investment of new capital in agriculture. But these developments were too slow and took time. In 1910 for instance, according to a Greek consular report ${ }^{19}$, the situation of the Hellenic population of the Vourla district was deplorable. The main produce, if not the only one of the region were currants, which were mainly for export. This meant that the welfare of the agrarian population was increasingly dependent on the prices fixed in Western markets. The poorer farmers were obliged to

18. Information from various sources quoted in Kontoyannis, ' $H^{\top} E \lambda \lambda \eta \nu \iota x \delta ́ \tau \eta$, p. 59-62; also Antonopoulos, p. 23, Rougon, ibid., and Novichev, ibid.

19. "Report on the situation of the prosince under the jurisdiction of the Royal sub-Consulate of Vourla», by the sub-Consul P. Capsabelis, 31 May 1910, in the Archive of the Greek Foreign Ministry. 
borrow from the rich land-owners at a $60 \%$ interest rate per year, which, as sub-Consul Capsabelis argued,

could well absorb the higher profits. If, in addition to that, we consider that most of the poorer farmers' land is mortgaged to the "Bank of Agriculture》 at prices representing not even a sixth or fifth of its salue, we have the real picture of the region).

Existing data corroborate that the Hellenic participation in advanced methods of cultivation was no bigger than the Muslim proportion, despite information to the contrary diffused by travellers or biased Greek scholars, who had been overimpressed by the vitality of the Hellenic element. In the vilayet of Aydin, for instance, according to Kontoyannis, there were 75,000 hectares of vineyards, mainly in the valleys of Hermus and Kaystrus, $75 \%$ of which were reported to belong to Greeks. Most of the 60,000 hectares of olive-tree plantations, according to the same author, belonged also to Greeks. The tobacco production, 5 - 12,000 tons per year, were also reported to be in Greek hands ${ }^{20}$. However, reading between the lines of Kontoyannis information it becomes clear that the Greeks were cultivating these crops as share-croppers.

On the big farms (çifliks) of this vilayet, ranging from 200 to 8,000 hectares ${ }^{21}$, share-cropping was almost exclusively adopted. The landowner supplied the land, the seed and the draught animals. At harvest time the landowner would take half of the crop after putting aside a proportion for the new seed. In the valley of Kaystrus, where the agrarian population was more dense, the landowner would take $a^{1 / 3}$ of the crops, while the share-cropper ${ }^{2} / 3$. In smaller çiftliks, in the 50 to 200 hectare range, proprietors would use direct cultivation with only partial share-cropping. Whereas, on properties of up to 50 hectares the owners would hire seasonal workers on a day to day basis ${ }^{22}$. As far as cultivation

20. Kontoyannis, Гewroapia, p. $362-3$; according to him $90 \%$ of the 30,000 seasonal workers packing dried figs, were also Greeks. (Figures are approximate).

21. The range is too wide. It is most likely that Rougon included also wakfs and state property.

22. Kontoyannis, op. cit., p. 364, and Rougon, p. 73-4. It should be noted that sometimes the Greek share - cropper used his own plough. Share-cropping was not always, as we saw, divided in halves. In Castamuni, for instance, where the land was owned by Muslim Government officials, the owner took $1 / 10$ of the crops in addition; see Kontoyannis, op. cit., p. 107; In Scala-Nuova (Nea Ephesos, or Kuşadası) the cultivation was made by the owners themselves; Rougon, ibid. 


\section{A. J. PANAYOTOPOULOS}

is concerned, we should also note that on the big çiftliks, which included arable land, pastures and forests, the extensive method of production was in use, while on smaller farms the method was both extensive and intensive. Taking into account the fact that the intensive method is required for the cultivation of specialized produce, we can see why agricultural production in the vilayet of Aydin was poor, while the region itself is more favourable than any other in the Ottoman Empire: most of the arable land of the vilayet was cultivated by the traditional extensive method ${ }^{23}$.

Most of the large estates of the Aydin vilayet were owned by Turks. In the region of Aydin, in the same vilayet, the land was the property of Turkish landowners but it was cultivated by a colony of Greeks who

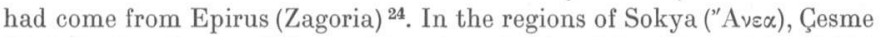

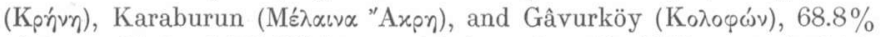
of the arable land (78,565 hectares) belonged to 18 çiftliks, out of which only one definitely belonged to a Greek, a medical practitioner named Klados. The other $31.2 \%$ (i.e. 36,500 hectares) was divided up into small, properties belonging to Greek and Turkish small farmers. Taking Poulakis' information that $80 \%$ of the population worked the land as reliable, we can arrive at some interesting conclusions. First, even though the Hellenic population was more numerous than that of the Turks, a higher relative proportion of the land was owned by Turks. The Greek smallholders constituted $80.1 \%$ of the rural population $(48,604)$ and owned 24,108 hectares, that is to say $67.7 \%$ of small properties, while Turkish small farmers $(12,054$ or $19.9 \%)$ owned $32.3 \%$ or 11,942 hectares ${ }^{25}$. Even if we consider that most of the Greeks established on the coastal regions were immigrants from the Aegean islands, Epirus and the Greek Kingdom, we find such a scale of ownership uncharacteristic of the Turks and note that it corroborates information about the gradual buying up of land by the Greeks ${ }^{26}$.

The Hellenic population of the interior was also mainly engaged in agriculture. In Axos (Hasaköy), for instance, a village of 600 Christian

23. Rougon, op. cit., p. 71, 74; also Novichev, op. cit.

24. A. Philippson, L'Hellénisme de l'Asie Mineure, Paris 1919, p. 27.

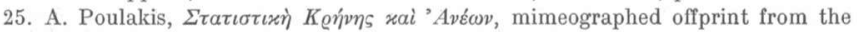

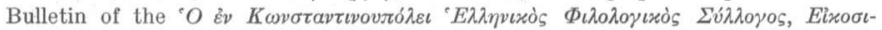

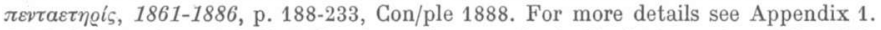

26. It is to be noted that the above figures refer to the last quarter of the 19th century. 


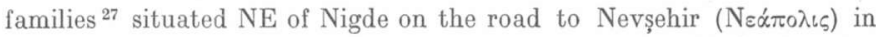
Cappadocia, landownership was shared as follows: a) The big landowning families with 50-80 Turkish strema each in their possession (8 hectares), only half of which were irrigated. They constituted $20 \%$ of the village population, 120 families in all. b) The small landowners, amounting to $60 \%$ of the population (360 families), who possessed $30 \mathrm{~T}$. strema each (3 hectares), half of which were under irrigation. And, c) the remaining $20 \%$ who possessed no property at all ${ }^{28}$. A big landowning family consisted of around 15 people: the paterfamilias, his wife, their 3 or 4 children with their spouses and the grand-children. A typical family owned 2 cows, 4-5 sheep, 1 donkey, 15-20 chickens, 4 oxen and 2 buffaloes. It also possessed 3 ploughs, 2 carts, 1 ox-cart and 1 buffalo-cart (sic). Share-cropping was the usual practice in the çiftliks, while small landowners could only cope by assisting each other ${ }^{29}$. Those without property worked for a daily wage plus what the landowner let them glean from the crops. The landowner cleared 950 grossia per year. They were enough to subsist on, but, according to Mavrochalyvidis, the various taxes on estates and on sheep, for army exemption as well as what was called the Metropolitan compensation, bribes and extra contributions caused serious hardship. To complete the picture, mention should be made of «communal» property, which most frequently belonged to the Church. It was mainly land rented to share-croppers, but we do not know its size ${ }^{30}$. The state of affairs described above existed during the first half of the 19th century. However, time worked against the relatively big Ottoman Greek landowners, whose holdings became fragmented as parts were inherited by their children. Thus, medium or small size properties became the general rule.

With the Hattr Humayun, the Sublime Porte accepted in principle that foreigners could buy and possess both urban and rural property. But it was only in 1867 (law of 13 Șefer 1284/16 June) that this principle acquired the force of law. The concession of the property right to foreigners, with the exception of the Henjaz region, was intended to promote industrial and agricultural production. As far as agriculture was concerned,

27. The population had increased to 900 families by the time of the exchange of population in 1924.

28. Mavrochalyvidis, op. cit., p. 75-6.

29. By share-cropping Mavrochalyvidis suggests that the small owners of land, rented their property to the big ones (sic). Thus, in his estimation of the large property, he includes several strema rented by the small landowners, op. cit., p. 81.

30. Op. eit., p. 82 and 163-4. 


\section{A. J. PANAYOTOPOULOS}

the promulgation of that law did not really help. Some of the main reasons for this were the lack of security in the interior, the arbitrary and oppresive behaviour of fiscal agents, and the non-existence of a quick, safe and regular transport network ${ }^{31}$.

The construction of the railroads was an important factor for change. The cultivation of specialized produce destined for the foreign markets, was extended. The increased revenue it earned brought into existence a stratum of profitable medium-sized agricultural units below that of the large çiftliks. But it also opened up the Ottoman home market to foreign manufactured goods, resulting in the destruction of local industries and increasing the peasants' need for money. This need strengthened his dependence on money lenders, who were either the Greek bakkals and millers, or bankers, Greeks and others. This tendency, however, only reached sizeable proportions at the beginning of the 20th century, and then mostly in Western Anatolia. "... Peasant land passed over to money lenders and merchants in payment of debts», wrote Novichev. Large landownership increased and the number of peasant-properties diminished ${ }^{32}$. O. Warburg, a German scholar, noted that in several provinces peasant-owned land constituted between 15 and $50 \%$ of cultivated land.

«The rest belongs to wakfs, the government or large landowners, who. . . also have the land worked by share-croppers, for the most part former peasant-proprietors $)^{33}$.

In fact, if we consider Mavrochalyvidis' figures about Axos in Cappadocia to be true and compare them with figures provided by the Codices of the Tameion Antallaximon for the same region during the second decade of the 20th century, we find a considerable fall in the agrarian population, in spite of a general increase overall. Only 200 families remained who lived exclusively from agriculture ${ }^{34}$. The agrarian population of Cappadocia in the 1920's was $54.5 \%$ while that of craftsmen

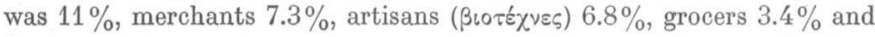

31. Rougon, p. 207, 209, 213; also Tranos p. 22-3.

32. The çiftlik of doctor Klados (5.000 hect.) in Gâvurköy, near Smyrna, is indicative of that process. Doctor Klados likely belonged to a family of bankers; see below, p. 113; also Poulakis, ibid.

33. Quoted by Novichev, op. cit.

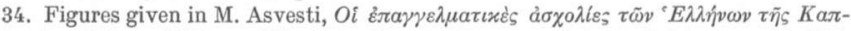

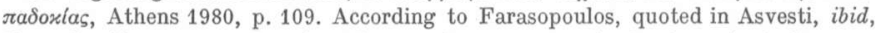
these families were approximately 400 (4,000 persons). Anyhow, in both cases figures are below average. For more details see Appendix 2. 
workers $2.1 \%$. It should be noted, however, that most of the Christian inhabitants of Cappadocia and of other parts of Anatolia as well, engaged in more than one job.

Philippson, obviously exaggerating, remarked about the coastal regions of Adramit and Ayvalik that there were no longer any villages that were purely Turkish in character. The more ancient among them had been "surrounded, strangled, devoured by large Greek çiftliks». The Turks had sold out to Greeks ${ }^{35}$.

\section{Trade}

We mentioned above the Law of 1867 concerning immovable property. That Law, intended by its makers to attract European investment, was complementary to other concessions granted in a treaty signed between Great Britain and Turkey about 30 years earlier, on August 16, 1838. It beame a model for other treaties of a similar kind and had in theory at least put the foreign merchant on the same footing as his Muslim counterpart.

There were three kinds of merchants in the Empire: foreign merchants (Müstemen Tüccart), Muslim merchants (Hayriye Tüccarı) and Imperial Christian merchant (Beratli Aorupa Tüccarı). The foreign merchants were not allowed to engage in internal trade and together with their Christian counterparts were involved in the import-export trade of the Empire. The signing of the 1838 treaty placed the tax-paying Muslim merchant in an uncompetitive position since it gave his foreign rivals the right to purchase free of tax whatever commodities they liked for both internal and external trade ${ }^{36}$. In practice, however, the foreign merchant was able to move freely and transact business only in certain coastal zones of Anatolia. There were several impediments, like his ignorance of the language and regional topography, the lack of a proper transport system and brigandage. Of necessity, intermediaries from the local population were in regular use. Most of these were Ottoman Greeks. Residing in the countryside, as well as in the cities, and having permanent relations with one another they came to acquire a powerful position in trade. They were familiar with local conditions and spoke Turkish and a European language besides. They regularly made use of favourable

35. Philippson, op. cit., p. 12, "Ce sont les groupements de terre pendues par les Turcs, ceux-ci ayant besoin d'argent et n'aimant pas le gagner en travaillant» (sic).

36. Köymen, p. 48-9. 


\section{A. J. PANAYOTOPOULOS}

laws deriving from the capitulations and enjoyed foreign protection. In their turn, they assisted the Europeans in their conquest of the Ottoman market. The Greek who had started as a wandering technician gradually dominated nearly every form of trade. Dufayard noted that

«leur rapidité de perception. . . leur esprit d'aventure et d'intrigue. . . leur passion de l'épargne, tout en fit... un peuple de négotiants» ${ }^{37}$.

And Sussnitzki remarked that the Greeks being

"native to the land and perhaps more, because of their fortunate distribution in cities and country. . have succeeded, in the course of time, in securing an extraordinarily strong position in commerce» ${ }^{38}$.

An interesting account of the Hellenic trade activity is also given by Ramsay:

«As soon as a few Greek traders established themselves in a district of Western Anatolia, the Turkish Governor who tries to go against them has a dog's life of it. They play into each other's hands; and they have on their side the Turk's despair in his own future and his belief that "Reform»... must come, and that, as it comes, it will sweep him away. The subject Greek feels that the sworld is with him; the Turkish Governor feels that it is against him» ${ }^{39}$.

In the 19th century, there were many large Hellenic firms, mainly in Smyrna. In the 20th century, however, they could be counted on one hand, the majority having been put out of business by German, Austrian, British and Armenian trading companies. The Greeks were reduced to running retail businesses dealing, however, directly with European markets ${ }^{40}$. But, as retailers they constituted a broad foundation for the wholesale trade of the eities. ${ }^{41}$.

If we are to believe a report dated 1911, made by the Greek Consulate in Smyrna, concerning the economic condition of the Greeks, the situation was not as bad as Antonopoulos would have us to understand. $80 \%$ of the merchants engaged in trade with the hinterland of the Aydin

37. Dufayard, p. 50.

38. Sussnitzki, op. cit.

39. Ramsay, Impressions, p. 134.

40. Antonopoulos, p. 146.

41. Sussnitzki, op. cit. 
vilayet were Ottoman Greeks. $50 \%$ of the export-import trade was also in their hands, and the remainder belonged to the French, British, Austrians, Italians, Germans, several Armenians and a few Turks and Jews ${ }^{42}$. The export trade was mainly in currants, figs, olive oil, cotton, acorns, cotton, seed, cereal, opium, opium seed, vegetables, aniseed, tobacco, soap, confectionery, silk, wine, chromium, skin, emery, etc.

There were 104 professions registered in the Guide of Smyrna, of the year $1888^{43}$. Greeks, regardless of their nationality, were preponderant. The figures contained in the Guide, though not accurate, give quite a satisfactory image of all the Hellenic firms worth mentioning. The main defect, however, and it is the one that characterises all data we have in our possession, is that there are no reliable comparative figures. We are thus, prevented from ascertaining accurately the extent of the Hellenic contribution to the commercial life of Smyrna. According to the Guide, merchants ${ }^{\mathbf{4 4}}$ were first in numerical strength: there were as many as 208 (of them) out of a total of 368 . Second came the agents ${ }^{45}, 71$ out of 78 ; third medical doctors, 41 out of 44 ; fourth sollicitors, 37 out of 65 ; fifth chemists, 34 out of 43; sixth bankers, 30 out of 44 ; seventh goldsmiths, 27 out of 40 , and spirit manufacturers 27 out of 31 ; eighth bakers, 26 out of 30 ; and ninth money lenders ${ }^{46}, 21$ out of 33 , wine markers 21 out of 25 , and butchers ${ }^{47} 21$ out of 23 . However, proportionate classification of the professions by percentages paints quite a different picture: butchers $91 \%$, spirit manufacturers $87 \%$, bakers $86 \%$, wine makers $84 \%$, chemists $79 \%$, agents $78 \%$, bankers $68 \%$, goldsmiths $67 \%$, money lenders $63 \%$, solicitors $58 \%$, merchants $57 \%$, and finally doctors $56 \%$. In 1911, within the jurisdiction of the Greek Consulate of Smyrna there were 68 solicitors, 80 doctors (64 in the city of Smyrna and 16 in the suburbs), and 36 chemists, 31 of whom were university graduates ${ }^{48}$. The chemists remained on the

42. The report just mentioned was written in 1911 by Smyrniot "experts" for the Greek Consulate. By Greeks, it means all those of Hellenic origin, irrespective of their nationality, i.e. Greek nationals or Ottoman Greeks. Hereafter this report will be referred to as the Economic Report.

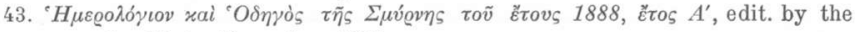
newspaper Amaltheia, December 1887.

44. Most likely retail dealers.

45. Not specified; there are also some other classifications, such as house agents, agents of colonial products, exchange agents, etc.

46. Or money-changers on occasion.

47. Meat-dealers (?)

48. Economic Report; To the best of my knowledge, there is no other data available to compare with that of the Guide. For more details see Appendix 3. 


\section{A. J. PANAYOTOPOULOS}

same level, whereas the doctors and solicitors increased in number considerably. Architects likewise doubled from 6 to 11 in 1911, while the Economic Report mentions 5 agriculturists, a profession not even listed in the Guide.

On the other hand, the French Consul Rougon mentions 94 trading companies, classified as follows: 33. French, including 2 Greek owners who were nationals of France. 2 Swiss, under French protection; 4 German; 7 English; 6 Austrian; 12 Greek; 5 Dutch; 10 Italians including 1 of Greek origin; and 15 Ottoman, including 10 who were Ottoman Greeks. The 2 French nationals of Greek origin imported manufactured goods, mainly clothing, from a number of countries. In the list of the Guide they were classified under the Shops for Clothes and Fashion. Of the 12 Greek subjects, 4 were bankers (same classification in the Guide); 2 were in the export trade; 2 were exporters and insurance agents (sic); 1 was in export-import trade; 1 in fashion and ready-made clothes; 1 dealt in spirits, and 1 was a commercial representative (proxy in the Guide). All of them were classified as merchants in the Guide. The Italian national of Greek origin exported the main domestic products (merchant in Guide). Of the 10 Ottoman Greeks, 3 exported acorns and other domestic products; 1 imported iron; 4 exported cereals and opium; 1 exported dried fruit, and 1 was a manufacturer. Only five of them were classified in the Guide as merchants ${ }^{49}$.

Neither the supremacy of European technology, nor the European capability to invest large sums of capital was ever challenged, not openly at least, by the Greeks. In contrast, the Armenians were considered to be tough competitors. They dealt not only in manufactured goods, carpets, zinc, various other metals and construction materials, but also to a lesser extent in all kinds of trade, just like the Greeks. In the countryside the bakkal, the inn-keeper (hancl) and the small shopkeeper who gave credit at usurious rates were all either Greek or Armenian. Both were very jealous of their position, hardly ever allowing anyone else to interfere in the domain of their activity. The regional separation based on the place of origin of each millet, i.e. of Greeks dominating in Western Anatolia and of Armenians in Eastern, only serves to mislead: their competition usually aimed at the extermination of each other, while less often they proceeded as though their objective was to divide up the market so that the two rival groups might be spared mutual competition ${ }^{50}$.

49. Rougon, p. 684-9.

50. Sussnitzki, op. cit.; also Antonopoulos, p. 21. 
The enterprising spirit of the Greek had frequently been misinterpreted as evidence of a graspingly selfish disposition, in contrast to the generosity displayed by the Turk. Ramsay maintained that this was an exaggeration:

"I have had more difficulties in bargaining with Turks... than I ever had with Greeks, and found them in a small way quite as grasping as any Greeks are... The instinct to trade and to haggle and to export is just as real in the Turk as in the Greek; but in the former it is often dormant, owing quite as much to pure ignorance as to real generosity ${ }^{51}$.

As a matter of fact, that dissimalirity owed more to the different circumstances in which Greeks and Turks found themselves than to anything else. It should be noted that similar differences existed between the Greeks of the cities and the Greeks of the countryside, especially those of the interior. In the second half of the 19th century V. Cuinet estimated that the Greeks of the interior were deprived of their original vivacity, because of the constant contact they had had with the Turks. But in self contradiction he concluded that being

«excellent farmers, practising also certain crafts which required skill, they share with Armenians the monopoly of commerce in the provinces of the interior. Under the present circumstances. . they are substituting the Turks as owners of their land, the latter being unable to develop it... In Greek hands, this land soon becomes productive

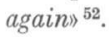

The estimation of the German scholar, K. Dieterich, in the 20th century, was much the same. The Greek city dwellers, according to him, were «subservient and cringing like the Armenians», while the peasants were

«energetic and intelligent, irreconcilable in their hatreds and by no means lacking in courage. And it is to these praisexporthy qualities, and not to their much bruited craftiness, that they owe their progress in the interior of Asia Minor ${ }^{53}$.

51. Ramsay, Impressions, p. 249.

52. Cuinet, op. cit., p. 356.

53. Dieterich, p. 52. 


\section{A. J. PANAYOTOPOULOS}

\section{Industry}

The «steady, inexorable, irresistible spread of European, and mainly of Greek influences in Anatolia, as Ramsay characterized it, was not envied or resisted by the Muslim. He entertained a stronger hatred towards the Circassian or heterodox Turkmen than towards the Greek or Armenian ${ }^{54}$, despite the fact that the Ottoman Greek acted as the middleman and his position in trade was due, as we have stated, to the tolerance of the Holy Law and the amazing misgovernment and incompetence not only of the Porte but also of the authorities of the smallest village. This situation, however, had such a bad influence on industry that Tranos, a Smyrniot merchant, was able to comment that,

"the capital owners do not invest, industry remains stagnant, and profiteering flourishes» ${ }^{55}$.

Though Anatolia was rich in raw materials, there was no industry worthy of the name. The only exception was textiles, in particular the weaving of carpets ${ }^{56}$. In the carpet industry there worked both Muslim and Christian women. The 19th century main carpet centre was Ushak with around one thousand looms, the property of small entrepreneurs, who were exclusively Muslim. But, gradually the Greek penetrated the field and towards the turn of the century 2,500 women, mostly Greek and Armenian, took the place of the Muslim. The looms were primitive, installed as they were in the very homes of the families who in most cases owned them and employed 4 to 5 workers. The day-wage was very low ${ }^{57}$, a fact which greatly increased the profit margin of the merchants, for the most part Armenians, who had comissioned the work ${ }^{58}$. Hellenic participation in the carpet industry seems to have been limited to supplying the labour force. In fact, only T.S. Spartalis and Co. are mentioned as carpet manufacturers ${ }^{59}$. This company kept working up

54. Ramsay, Impressions, p. 94, 134.

55. Tranos, p. 23.

56. Tranos, p. 22, Rougon, p. 69 and Antonopoulos p. 21; see also the Economic Report.

57. Before the European War, the day-wage was $1-1 \frac{1}{2}$ golden grossia in the

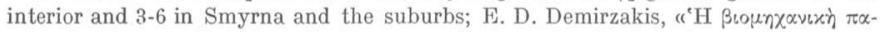

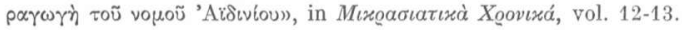

58. Rougon, p. 284-9, Antonopoulos, p. 21 and Guide, p. 206.

59. Spartalis is mentioned by Rougon as a manufacturer, whereas by the Guide as a merchant. It is worth noting that in the Guide, from the 13 classified carpet dealers none is Greek, ibid. 
to the end of Hellenism in Anatolia. In the 20th century, two more Greek companies began to function: Gregoriadis and Co., and F. Kahramanoglu. In 1908, a British company «The Oriental Carpet Manufacturers Ltd", started production. Its initial capital of $£ 400,000$ was increased to $£ 1,000,000$ in 1912 . The «Oriental Carpets» came almost to monopolizing the market and absorbed the biggest part of the Greek labour force working in that field. It possessed, throughout the vilayet of Aydin, 1,570 looms and employed 6,400 women, of whom 4,400 were Greeks ${ }^{60}$.

Apart from the carpet industry, which contributed in no small way to the export trade, factories merely catered to domestic needs. Among them, however, some were well equipped, such as certain flour mills, iron-works and iron and glass foundries. The first factory to use steam power to be established in Anatolia belonged, according to the Guide, to the Ottoman Greek D. Issigonis, whereas, according to Poulakis, it belonged to the British "McAndrews and Forbes». Both sources date both factories from 1856. The «Issigonis» factory was characterized by Rougon as the most perfect of its kind, and, with its 75 horse-power engines, employed from between 150 to 250 workers according to the season. It included machine-works, iron-works, and a foundry, as well as mechanized joineries. In 1887 it opened a new department to make iron-needles ${ }^{61}$. "Mac Andrews and Forbes», was the other big factory which competed against that of "Clark», established in 1854. In order to cope with their competition, Clark founded a new steam-powered factory in 1859. "McAndrews and Forbes" bought it up and afterwards closed it down. «McA\&F» factory processed agricultural products, mainly liquorice. For that reason, it took all the liquorice producing land of the Meandrus valley on lease for nine years and in that way monopolized the market ${ }^{62}$. There was also the factory of the Greek N. Karamaniolos, established in 1877. It had 60 horse-power steam engines and employed around 200 workers. It included machine-works, mechanized wood-works, a cotton-processing department producing 120 Kele $/ 24 \mathrm{~h} .(1 \mathrm{k}=17$ okes*), and also a flour-mill ${ }^{63}$. The wood-works departments gave a new impetus to the manifacture of furniture, impeding at the same time the imports from Europe.

\footnotetext{
$* 1$ oke $=1280 \mathrm{gr}$., and 1 litre $=920 \mathrm{gr}$.

60. Demirzakis; figures are of 1919.

61. Rougon, p. 261-3, and Guide, p. 317.

62. Poulakis, p. 48, 50-1.

63. Poulakis, p. 317, Rougon, p. 263.
} 


\section{A. J. PANAYOTOPOULOS}

The flour-mills played an important part in the industrial life of Anatolia. There were about 23 of them in all: $10-12$ were steam-driven; the remainder, traditional watermills ${ }^{64}$. Four of the steam-powered mills belonged to Ottoman Greeks. Mention has been made above of N. Karamaniolos. Another mill belonged to M. Nicolaidis, which had 6 millstones and a daily capacity of 600 kele (14,190 litres /24h). A third was owned by Marcopoulos-Hadjiantoniou and Co., and also had 6 millstones with a capacity, however, of $800 \mathrm{k}$ (18,920 litres $/ 24 \mathrm{~h})$. The mill that completes this list was bigger than the other three and was owned by CousinerisPittacos, who were also French subjects. It had 9 stones and 1 roller-mill and a capacity of $1,250 \mathrm{k}(29,565$ litres $/ 24 \mathrm{~h})$. The overall daily production was $1,800-1,900$ hectolitres ${ }^{65}$. The above means that the Hellenic contribution to flour production was at least 62,675 litres $/ 24 \mathrm{~h}$, , or $34 \%$ of the daily production. In 1911 there were still ten flour-mills worth mentioning. Four of them belonged to Greek subjects (Karamaniolos, Faypeas, Tsintsinias, Vintirosos); 2 belonged to Ottoman Greeks (Girkalos, Tozakoglou and Stefanidis); 2 belonged to Marcopoulos, who had amalgamated with the Italian Magnifico and changed his nationality to Italian as well; 1 to the Austrian, Jean Braggiotti and one to the Ottoman Greeks(?) Mouratis and Mindissoglu. The Greek contribution to the daily production (Greek nationals and Ottoman Greeks - not including Mouratis-Mindissoglu and Magnifico-Marcopoulos) was around 7,450k. (176,210 litres), or $65.3 \%$ of the whole $\left(11,400 \mathrm{k}\right.$ or 269,635 litres) ${ }^{66}$. Apart from these factories there was also the local industry, if we may call it that, supplying exclusively local needs. There were hundreds of small tanneries, ironworks, flour-mills and dye-works scattered all over the interior. We should also mention several soap-works, silk and candle manufactories, as well as a few boat yards (tersane) where the famous caiques (kayik) were built ${ }^{67}$.

In 1911, Smyrna was still an important industrial centre. The main sector was the carpet industry, which in the town of Smyrna itself was in the hands of foreigners, while in the interior it was in Greek and Turkish hands. On the other hand, flour-mills, soapworks, confectionery, the making of boxes for figs and currants continued, however, to constitute a considerable factor in industry. Figures supplied by the Economic

64. Guide, p. 213, Rougon, ibid.

65. Rougon, ibid.; also Guide (in the List).

66. Economic Report, op. cit.

67. Rougon, p. 261, and Guide, p. 213. 
Report indicate that the Greeks had a $90 \%$ share in this activity ${ }^{68}$. It is obvious, however, that most of this so-called industry was small-scale as it was the capital invested by Ottoman Greek «industrialists». There were only about 10 real industrial plants and these were owned by European limited companies. Not one single Greek limited company with Greek founders, share holders and directors existed in Anatolia.

The Hellenic economic development was on an individual basis. Greek «industrialists» did not associate together in order to organize big units. Under the circumstances, "familism» became their main characteristic as well as the main reason why «though dominating in numbers and endurance, they did not follow the latest developments in their industrial activity" ${ }^{69}$. But it would be unjust to ignore that this state of affairs was mainly due to the lack of large sums of capital and of technical knowledge ${ }^{70}$.

Education was yet another reason why Hellenic industrial development did not manage to keep pace with that of the European. The Hellenic communities were well known for their ambition to educate their members by founding and equipping schools, some of which became real centres of Hellenism. In most cases, however, their syllabuses did not meet the practical needs of every day life. They exclusively concentrated on a study of classical letters and cultivated contempt for any knowledge that would have helped Hellenic trade, agriculture and industry to catch up with their Western rivals. Moreover, the Hellenic educational system was discouraged, in every way possible, from taking a practical and technical orientation by the general administrative and economic situation of the Ottoman Empire. The prevalent pedantry was, however, primarily the result of Greek foreign policy, which aimed at transmitting the views of Greek irredentism to Anatolian Greeks, and which gave financial aid in order to keep alive or even create, in some instances, Greek national consciousness among them.

A nationalism of this kind, which appealed mainly to the emotions, was criticized particularly by the Greek nationalist, Ion Dragoumis. Dragoumis maintained that improving the material well-being of Ottoman Greeks was the way to keep alive their national consciousness.

"Schools, churches, hospitals, communities and nexspapers are not as important as economic dependence on the Centre (Greece)... Greek

68. Economic Report, op. cit.; for details see Appendix 4.

69. Demirzakis, op. cit., p. 22.

70. See the interesting book by D. C. Blaisdell, European Financial Control in the Ottoman Empire, New York, 1929, p. 75. 


\section{A. J. PANAYOTOPOULOZ}

enterprises and cooperatives, based in Greece and working with Ottoman Hellenism, should be started. . . Care should also be taken to promote Greek products through Greeks living abroad, and to make these Greeks act as agents of Greek commerce. ..» ${ }^{71}$

Nonetheless, the ancient Greek language and literature remained the main vehicles of Greek nationalistic propaganda and were, therefore, systematically taught in the schools. History, some geography and a few crumbs of mathematics were deemed adequate to complete a school education.

«Il règne matheuresement dans nos moeurs extérieurs. . et jusque dans notre enseignement une fausse pudeur, une pruderie hypocrite qui empêchent d'avouer la poursuite des richesses comme un but légitime d'occupation... Nous aspirons à des occupations libérales, dédaignants le travail industriel. Voilà pourquoi nous manquons içi d'agriculteurs sérieux, de filateurs, de tanneurs, de fabricants de vins et d'huiles... Ce n'est que lorsque des étrangers... viendront s'enrichir sous nos yeux que nous sortirons de notre apathie, de notre coupable assoupissement pour pousser des hauts cris de désespoir et les accuser d'usurpation et Dieu sait de quoi encore» ${ }^{72}$.

Another obstacle in the way of economic development was created by the inefficient application of the law exempting from tax all machinery imported for manufacturing purposes. Red tape and the reluctance for diverse reasons of officials in the Customs to pay heed to the law had a demoralising effect on the local people interested in investing in industry. In addition to this, the practice of bribery could be seen to be flourishing unabatedly ${ }^{73}$. Years later, Demirzakis deplored the disorganized and individualistic way of acting of the Ottoman Greek entrepreneurs. But in fact, Greeks from 1891 to 1900 established 443 industrial units as against 98 established by the Turks. and from 1901 to 1910 a further 437 as against a mere 58 by the Turks. Overall there were 5.308 units employing 37.185 workers. Among them 4,008 were

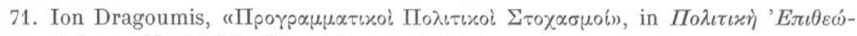

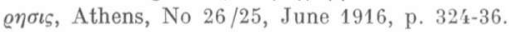

72. D. Georgiadès, Smyrne et l'Asie Mineure au point de pue économique et com-

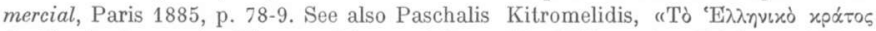

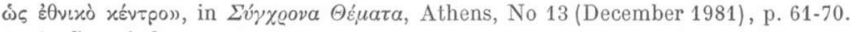

73. Georgiadès, p. 74. 
Ottoman Greek with 28,166 workers and 1,216 were Turkish with 5,766 workers. But 13 English units employed 1,489, 2 American ones employed 290 workers and 1 Belgian 528 workers. The total number of workers employed by each national group of industries is indicative of the size of the units. The Hellenic rate was 7 workers for each plant and workshop and the Turkish rate was 4.7 workers, while the English rate was 114.5, the American even higher with 145 workers, and the Belgian highest of all with 528 workers ${ }^{74}$.

The above figures look inflated because Demirzakis uses the term industry in its wider sense, understanding by it not only factories as such but also small manufacturing companies and a large number of workshops, in which he even includes family-owned looms. Thus, the main bulk of the 37,185 workers (not counting 1,500 of the Aydin and Kassamba railway companies, and the 4,000 of the Régie Ottomane de tabac), were employed firstly in workshops and secondly in factories $(23,666) .95 \%$ of the workers of the Aydin vilayet belonged to the Hellenic community, but there were also Greek subjects. The Greeks «pere active in factories, partly as engineers and technicians and partly as entrepreneurs» ${ }^{75}$. Both foreign and Greek «industrialists» preferred Greek employees. In Greek factories, however, the chief engineers and workers were usually either English or Swiss. Greek women to a high degree were also engaged in factory work. On the other hand, Turkish males "in spite of their capacities as craftsmen", kept away from the factories, as did Turkish women to an even greater extent ${ }^{76}$.

In industry, as in trade, there existed a sort of millet specialization in the kind of employment preferred. That division was linked with certain traditional crafts. Thus, the Turks were able saddlers, silkweavers, dyers, iron and coppersmiths and armourers, while the Greeks were predominantly brick-layers, joiners, smiths, wagon-makers, winemakers and mechanics (sometimes even watch-makers). With the gradual increase of industrialization, however, that division along with sex-discrimination became less marked and was to vanish after World War I. In the meanwhile, a migration was to be observed from the various workshops to the respective factories. The Turk saddlers, for in-

74. The figures supplied by Demitzakis, op. cit., are for 1919 after the vilayet had been occupied by the Greek Army. Nonetheless, we think they are at the levels before 1912. The increases from 1912 - 1919 balance the losses caused by the Turko-Balkan war and the Ist World War. For more details see Appendix 4.

75. Sussnitzki, op. cit.

76. Ibid.; also Demirzakis, op. cit. 


\section{A. J. PANAYOTOPOULOS}

stance, the traditional tabaklar (tanners), gradually moved to the mechanized tanneries ${ }^{77}$.

There is a view which holds that the Muslims were mostly employed as unskilled workers, porters, etc., while Greek workers were better off, because of "the well known intelligence of the race, their industry and frugality» ${ }^{78}$. This view does not seem to be absolutely correct. Demirzakis himself stated that uthe condition of the Smyrna working class was miserable». They lived mainly in Pounta, the industrial zone North-East of Smyrna.

"Malnutrition, bad housing, humidity and malaria made them sluggish, slow-minded and lacking in skilfulness in comparison with their counterparts in the Greek Kingdom. They also lacked specialized technical knowledge. Any consciousness of belonging to the working class or to a professional class was equally absent» ${ }^{79}$.

Yet, that working class, still only partly formed, showed remarkable militancy during the strikes that followed the 1908 Young Turk revolution. Most of these strikes were set up quite spontaneously, with the minimum organizational preparation and were the result of years of economic, social and psychological oppression. The dockers of the Quai (Prokymaia) and the porters were the first to go on strike in Smyrna. After a while, there were strikes in every sector, showing two remarkable points: a) that the Greek workers ${ }^{80}$ seemed to lead these strikes and b) that a fraternity existed between Greeks and Turks. On the other hand, the Young Turk Committee, and the Hellenic newspaper Amaltheia which was expressing the official Hellenic view, condemned the strikes as discrediting the newly acquired constitutional freedom to Europe. Soon afterwards the CUP passed a law forbidding strikes ${ }^{81}$.

Nonetheless, workers' newspapers made their appearance in Smyrna, Salonica and Constantinople and several socialist circles were formed. Attempts were also made by the exponents of Ottoman socialism to formulate a supranational policy. The most outstanding expression of that policy was their opposition to the partition of the Empire and to

77. Sussnitzki, ibid., Demirzakis, ibid.

78. Demirzakis, ibid.

79. Demirzakiș, ibid.

80. It should be noted that most of them were Greek immigrants, but not necessarily Greek subjects.

81. Amaltheia, 29 July; the law was promulgated in October 1908. 
the Balkan war of 1912. However, the Ottoman labour movement did not succeed in going beyond that initial stage of spontaneous or halfprepared strikes and proclamations, and was unable to exert any serious influence. What was clearly demonstrated though, was the fact that the Hellenic element in the working population played a leading role in the Ottoman labour and socialist movement ${ }^{82}$.

\section{Mining and Banking}

We mentioned previously that opportunities in trade, with its large profit margins, along with insecurity in real property (being subject to arbitrary taxation and the high risk of confiscation) led the more affluent Ottoman Greeks to invest their assets in commerce and financial activity rather than in manufacturing or mining adventures. Mining remained in a primitive state, while banking flourished, as the Ottoman Greeks had no other method of securing their fortunes after having retired from trade.

Though Anatolia is rich in mineral wealth, mining did not attract serious investment. Protective legislation existed, but it remained a dead letter. Mineral deposits had never been systematically surveyed and incompetent persons possessing very little capital undertook these mining operations. A number of Greeks, Avghérinopoulos and Cottaris, Paul Homère and Coronios, a banker from Constantinople, as well as Pittacos, a French national, ceased mining work because of shortage of money and because they could not or would not invest in large-scale projects, requiring organization and planning ${ }^{83}$.

The only regularly exploited mine to continue, to function into the 20th century was that of silverbearing lead in Balikesir. The company in charge of operations also exploited the Lavrio minefield in Greece. Capital investment was 'predominantly French in origin but there were at times Greek investors like Serpieris and Rallis, who also were directeurs de travaux the former at the beginning of the works (second half of 19th c.) and the latter after the turn of the century. A large number of Greek immigrants followed these two Greek managers to Asia Minor. They settled in Balikesir and worked not only for the mining company, but in agriculture as well ${ }^{84}$.

82. About the Greek workers mobilization in the Ottoman Empire after 1908, see A. Panayotopoulos, "The Hellenic contribution to the Ottoman labour and socialist movement after 1908m, in Études Balkaniques, $1980 / 1$, p. 38-57.

83. Rougon, op. cit., p. 164-6.

84. Rougon, p. 163, Philippson, p. 13. 


\section{A. J. PANAYOTOPOULOS}

Banking, which in contrast to mining was a favourite branch of Hellenic activity, also deserves separate mention. Rougon, as we have seen, mentions four Greek bankers established in Smyrna, whereas the Guide mentions thirty out of a total of forty four ${ }^{85}$. However, the main banking houses were established in Constantinople, though the imperial City could not be rightly called a great commercial centre.

The business life of Constantinople had two main aspects: a) Import and distribution of foreign manufactured goods, and b) collection and export of goods, mostly raw materials. The import trade was in the hands of Greeks, Armenians and Jews, who were either native or under foreign protection. They bought manufactured goods in foreign markets either directly, or through agents or through their own houses in England and in France. They then sold them to merchants from Thrace and the coasts of the Sea of Marmora and the Black Sea, who bought either on sample or from stock. The collection of Turkish products for export was largely done by foreign firms at Constantinople, but native Greeks, Armenians and Jews had a considerable share of this trade. The peculiarity of this trade was that the goods for export, purchased through agents in various towns of Asia Minor, were sent to Constantinople, where they were often sold and resold several times before eventually being exported ${ }^{86}$.

Hellenic (and Greek) commercial activity was backed by several banks, which were organized on a share holding basis and functioned as limited companies (S.A.). Apart from certain big foreign banks, like the Imperial Ottoman Bank or the Crédit Lyonnais, all the others either belonged to Ottoman Greeks or had Ottoman Greek shareholders with a controlling interest. It is worth noting that the Imperial Ottoman Bank was established in 1863 and that one year later, in 1864, it took part along with Ottoman Greek bankers in the foundation of the Société Générale de l'Empire Ottoman. These bankers were Aristidi bey Baltazzis, Christos effendi Zographos, A. A. Rallis, Zanis Stefanovik and Co., Alvertis and Co., J. Kamondos, Zafiropoulos, Zarifis and others. Stefanovik was president of the Administrative Council and George and Leonidas Zarifis were members. The business of the bank, which had been granted a 30 year charter was as follows: participation in or conclusion of domestic or foreign loans with the Imperial government or the provincial and municipal authorities, buying and selling of bonds, foundation of or parti-

85. Rougon, op. cit., Guide, op. cit.

86. Turkey in Europe, Handbook prepared under the direction of the Historical Section of the F. O., London 1920, p. $104 \mathrm{ff}, 109$. 
cipation in industrial, commercial and financial businesses, as well as in public works, etc. Its annual turn-over was T£. 1,078,414.

In 1869 the Crédit Général Ottoman was founded by French capital owners and the Hellenic Touvinis Banking House. Yakinthos Touvinis became president, and B. Touvinis, J. Lorandos, Z. Stefanovik were Council members. Its transactions were with the Government and the Ministries and it had an annual turn-over of T£ 2,868,756.

The Banque de Constantinople and the Société Ottomane de Changes et de Valeurs were two more important Hellenic Banks. The former was established in 1872 by A. Vlastos, A. D. Sygros, G. Koronios and S. Skouloudis. G. Zarifis and O. Negropondis also had shares in the company. The latter was established the same year by P. M. Klados ${ }^{87}$, E. Evgenidis and A.J.F. Barker, with the participation of V. Evgenidis and D. Andreas. Its business was stock-brokerage, money-changing, precious metals, etc. ${ }^{88}$.

In 1870, the Imperial Ottoman Bank, and the Société Générale associated with the Camondos Co. and with the bankers Christaki effendi Zographos and G. Zarifis, and with K. Karapanos, who possessed the imperial irade (permission) to found a tramway company. What followed is a typical example of how public transport, though meant to promote social welfare, became the centre of much profiteering. A Société des Ttamsways was founded. The shareholders, however, were more involved in trying to ruin each other than in the actual work for which the Société had been established. Increases and decreases of capital often took place and eventually the company annulled 3,133 shares and put only two lines into service, those of Galata and Pera. It is worth mentioning that after the turn of the century, the company had not yet solved its problems, as was revealed by a strike of its Hellenic and Armenian staff. The strikers demanded, in addition to other things common to all strikes which took place after 1908, the replacement of the General Manager and main(?) shareholder, A. Perdikaris. Perdikaris accused the newspaper Sabah of instigating the Armenians to oppose him and gave it to be understood that nationalistic and other political reasons were the real motives for the strike. He, moreover, maintained that since he became the main shareholder, he supported the Hellenic staff but he also stated, in self

87. Most likely of the same family of Klados, who owned a large fiftlik near Smyrna.

88. The former's annual turn-over was T£. 1,552,404, and the latter's T£. $1,116,043$. 


\section{A. J. PANAYOTOPOULOS}

contradiction, that the Hellenic staff was the most numerous, while most of the capital was foreign ${ }^{89}$. Unfortunately, sufficient evidence is lacking to enable us to reach sound conclusions.

Completing this section, we should also mention that in the 20th century the most influential of the Greek and Hellenic banks operating in the Empire was, according to British evidence, the Greek Banque d'Athènes. It had agencies in almost all seaport towns and its business, mostly with Greek subjects, was purely commercial ${ }^{90}$.

\section{Conclusions}

Most of the Hellenic population of Anatolia was engaged in agriculture, not only in the hinterland of Anatolia but also in coastal areas. The majority owned medium or small sized farms, but large numbers were also share-croppers. However, what assured them a better position than their Muslim compatriots was the kind of crops they cultivated, especially on the meridional coasts.

Another essential difference between the Christian and Muslim millets was that more Greeks than Turks were occupied in trade, an economic area in which large profit margins were the rule. This was the most striking feature of Anatolian Hellenism, creating the erroneous impression that the Hellenic millet enjoyed a state of general well-being.

In the cities, the bulk of Anatolian Greeks belonged to the middle strata and were principally engaged in the retail business. But there were also substantial merchants engaged in the import-export trade, and a considerable number of working class people employed seasonally or permanently. Industry and trade, were for the most part in Hellenic hands, as also was banking. This was due to several reasons. In the first place, almost all the Hellenic communities, were located in areas favourable to the development of trade. Proud of their military tradition, Muslims used their power and the machinery of state to dominate the subject millets. Contemptuous of involvement in trade, they gradually allowed all economic activity to pass completely into the hands of those they despised ${ }^{91}$. Exempted from service in the army, the latter could

89. P. Thomas-A. Paleologos, Diary, p. 273-93; also newspaper Proodos, 3 September, 1908.

90. Turkey in Europe, op. cit., p. 134.

91. K. Karpat partly denies that view and maintains that a study based on the documents from the Phanariote period in the Bucharest archives. . shoss that (at least) in the period ca 1740-74 ... there spas a ban secured by the Phanariote rulers of $W$ al- 
only prosper. Christians spoke the Turkish language fluently and were conversant with the manners and customs of Muslim society. Either in association with foreign traders or on their own, Anatolian Greeks made good use of the trading concessions granted to outsiders and consequently experienced a rise in living standards. Bertrand wrote that

«non seulement le prolétaire grec ou arménien est d'une autre race que le prolétaire musulman, mais ses qualités acquises lui confèrent, pour la concurence vitale, une supériorité écrasante sur ce dernier»" ${ }^{92}$.

The 1908 strikes, however, amply showed that Greeks and Turks of the working class were equally deprived, and that they were both anticipating the Young Turks' assistance to relieve their misery.

The Smyrniot merchant G. M. Tranos believed that the main reason for the backwardness of all Ottoman millets was the Ottoman Public Debt, which through the Régie de Tabac and indirect taxes absorbed all the wealth of the Empire. He characterised the Debt and its creditors as a "state within a state», who looked upon the Ottoman Empire as a cow to be milked dry, and reacted to any administrative improvements ${ }^{93}$. Tranos might have been exaggerating as far as administrative changes were concerned, - in fact the Powers welcomed these changes if they did not conflict with their own policy. But, Tranos was quite clear in wanting the abolition of the Public Debt and the control over economic activity of foreigners inside the Empire. Georgiadès, whose book had appeared almost thirty five years earlier, agreed that

«les puissances désirent nous poir toujours les clients-esclapes de leurs fabricants et ne négligent aucun moyen pour nous imposer des tarifs fort peu onereux pour l'entrée de leurs produits en Turquie» ${ }^{94}$.

An example showing that Western powers were narrowly pursuing their own interests can be seen in their reaction to the proposal made

lachia from the Ottoman Gosernment. . prohibiting... Turks from engaging in economic occupations and in the investing in the agriculture of that regions; aThe stages of Ottoman History (a structural comparative approach)», p. 93, fn1, in The Ottoman State and its place in World History, by K. Karpat and contributors, Leiden, Brill, 1974.

92. Quoted in L. Maccas, L'Hellénisme de l'Asie Mineure; son histoire, sa puissance, son sort, Paris 1919.

93. Tranos, op. cit., p. 24.

94. Georgiadès, op. cit., p. 72. 


\section{A. J. PANAYOTOPOULOS}

by Greek Smyrniots for the junction of the Haydar Paşa-Konya railway with the Kassamba railway at Karahissar. The Germans who constructed the Haydar Paşa railway, refused to link them up to the detriment of Smyrna's commerce. The Hellenic newspaper Amaltheia of Smyrna, expressing the feelings of the majority of the town's Hellenic community, bitterly regretted both the German unwillingnes and the Young Turks' undifference, which made their town lose «its commercial future» ${ }^{95}$.

D. Blaisdell had the same opinion about the role of the Great Powers. He noted that European industry and commerce had expanded at an enormous rate during the 19th century; consequently, he argued,

«a consuming Turkey (largely agricultural and with fes native manufactures) would offer a large market for surplus European manufactures. On the other hand, a Turkey with liberal movements, with education, and with the practical sciences developing natural resources and production svould mean that many needs of the population would be provided by products of home manufacture, and would diminish Europe's market accordingly" ${ }^{96}$.

As it has been shown, European economic expansion in the 19th century and the internal decline of the Ottoman Empire opened up the latter's large home market to European penetration. The Hellenic millet functioned as the middleman between the Muslims and Europe. That role permitted Ottoman Greeks to form by and large a petty bourgeoisie of entrepreneurs, traders, moneylenders, brokers and commissioners, and to staff the liberal professions with pharmacists, engineers, solicitors, architects and doctors, whose skills are required by a developing society. The majority, however, remained the salaried middle-class, or the skilled and unskilled urban working class. Thus linked with European capital on the one hand, and culturally segregated from the Ottoman society by the traditional discriminatory distinction between the dominant Muslims and the rayah non-Muslims on the other, the Ottoman Greeks were obliged to follow the growth and decline of European influence in the area, as well as the fluctuation of relations between the Empire and Greece.

95. If the two railways joined, the newspaper argued, "our town would become once again the commercial centre of the hinterland, as it always used to be. . Instead, with the German railspay, goods that at one time spere transported to Smyrna are now diperted. Thus our town. . . has been enclosed within a certain periphery, beyond which it cannot have any claim"; Amaltheia, 5 Aug. 1908.

96. Blaisdell, op. cit., p. 19. 
After the Young Turks assumed power in 1908, it became apparent in certain influential Ottoman Greek circles that Ottoman society had become deeply concerned by the role being played by the Hellenic millet and showed signs that it was determined, even if it was not ready, to undertake these middle class functions itsef. The newspaper Amaltheia, voicing the views of these circles, wrote about the economic situation of the Empire and identified its economic interests with those of the Hellenic millet. Inspired by the boycott of Austrian goods declared by the Young Turks as a reaction to the Austrian annexation of Bosnia and Herzegovina, the newspaper urged the Young Turks to lead these "patriotic attitudes... towards the encouragement and development of domestic industry , and not to let them become a mere passing sentimental expression.

"Let us hope that all citizens will attempt to convince the Government that they will not tolerate any longer European industrialists, who soak up the wealth of the country, and they wish... the creation and consolidation of national industries ${ }^{97}$.

The newspaper did not clarify what it meant by «national industries», but obviously identified Hellenic economic interest with that of the Empire. It even went so far as to express its approval of the rumours then circulating about the abolition of capitulations.

"These are the sole reasons for the country's poverty. . The Ottoman State. . . is lacking any industry worthy of the name, because Europe, which makes jealous use of old capitulations, has always acted in a most niggardly fashion.

... How is it possible to develop domestic industry when the capitulations deprive it of the right to impose protective import duties?... European industry looks upon the large Empire as a consumer... and not as a rival. Our ras materials are exported to Europe and then sent back to us in the form of manufactured goods that are five times, even ten times more expensive... We had hoped that the new institutions would release our country from its economic subjection... But surprisingly enough, we see that this release is offered to Turkey in compensation for the prosinces and the rights that the Posverful had robbed from her... The Young Turks freed the country from the

97. Amaltheia, 30 Sept. 1908. 


\section{A. J. PANAYOTOPOULOS}

apolytarchy. Let the latest misfortunes serve to release it from the subjection and slavery of European industry" ${ }^{98}$.

Far from being self-centred in a narrow ethnic sense, leading articles of the kind just referred to in Amaltheia expressed the wishes, opinions and ambitions of Hellenic traders and industrialists who contemplated remaining permanently within the Ottoman State ${ }^{99}$. But, precisely because they were not Muslims and were identified with the irredentist nationalism of Greece, they had always been suspected of wishing to undermine the Empire. Every one of their proposals was received with suspicion by the Porte and only adopted as a concession to the nonMuslim population. Furthermore, the embryonic state of the Turkish middle class meant that only Anatolian Greeks would reap benefit from the adoption of such measures.

Ottoman suspicion was fed by the lack of any Greek Government strategy. Broadly speaking, Athens had adopted an irredentist policy for domestic consumption. But being aware of its weaknesses, the Greek State was forced to keep a low profile externally. It is true that Greek propaganda aimed at the revival or creation of Greek national consciousness and identified it with the Hellenic ethnic consciousness. The main vehicle for the promotion of the ideal of Greek irredentism was the University of Athens. Greek teachers, graduates of it, were sent mainly to the big urban centres of Anatolia. Through the Hellenic community schools they tried and in part succeeded in placing Ottoman Hellenism «within the symbolic and psychological system of modern Greek nationalism》 ${ }^{100}$.

However, it did not become clear to what use Athens would put this feeling. It seemed to follow a cautious policy of «wait and see», and sometimes intervened in an awkward and inefficient manner. Did Greece want the integrity of the Ottoman Empire or did it work for its partition?

98. Amaltheia, 6 Octob. 1908.

99. If the above mentioned articles of Amaltheia supported most prominently the economic strengthening of the local element, other less overt articles were also printed on the same subject. On the occasion of the foundation of an international Commercial Association in Smyrna, for instance, Amaltheia urged local Greek businessmen to give it their support for their own benefit: the transport of the goods, their disctribution, as well as the conditions of their export, were often so disadvantageous that the merchant shied away from a transaction in order to safeguard his working capital; ibid, 11 Sept. 1908.

100. P. Kitromelidis, op. cit. 
The Sublime Porte was never convinced of Athens' sincerity, and Athens itself was not sure what attitude to adopt, since almost all previous conflicts with the Empire, successful or not, had resulted in the expansion of Greek frontiers. But such a policy was incapable of promoting Anatolian Greek interests, least of all in the economic field. That became apparent particularly after the restoration of the constitution by the Young Turks in 1908, when Muslim fanaticism was gradually replaced by Ottoman and Turkish nationalism.

If the declining Empire offered a large unexploited market to Western European industry and within that framework permitted Hellenic economic growth, the constitutional Empire of the Young Turks with its latent nationalism called for clarity of aims from all interested parties. Greece definitely ought to have clarified whether she accepted the status quo or whether she would adopt an expansionist policy. In the latter case, the position of Hellenism inside the Empire would have become very tenuous, and strict economic measures would have been taken against Ottoman Greeks to weaken their position.

The Greek state was either too weak or too confused, ideologically speaking, to reach any decision. That attitude was only finally abandoned when E. Venizelos came to power. Territorial claims against the Empire became Venizelos' foreign policy, thus giving shape to the Greek «Great Idea». Nonetheless, subsequent events were to show that the policy of «wait and see», though apparently indecisive and ineffective was not devoid of practical advantages. If we mentioned one, it would be the rapprochement of the Balkan millets living inside the Ottoman State; a rapprochement which paved the way for the Balkan Alliance and for Greece's eventual acquisition of Macedonia and Western Thrace. The most important advantage, however, as far as the Ottoman Greeks were concerned, was that it permitted their economic development and did not impede the development of their particular ethnic consciousness. From the moment that Greece decided that the essence of its «Great Idea» was the grouping of all Greeks within a single state it was apparent that Anatolian Hellenism could not survive in the hostile milieu of increased Turkish nationalism. The real end of Anatolian Hellenism, therefore, did not come ten years later, in 1922, but with the successful conclusion of the Balkan war of 1912 .

ALKIS J. PANA YOTOPOULOS 


\section{APPENDIX 1}

TABLE 1: LAND DIVISION IN ÇESME PENINSULA

\begin{tabular}{|c|c|c|c|c|}
\hline \multirow[t]{2}{*}{ Districts } & \multirow{2}{*}{$\begin{array}{l}\text { Number of } \\
\text { big farmers }\end{array}$} & \multicolumn{2}{|c|}{ Hectars ospned by } & \multirow{2}{*}{ TOTAL } \\
\hline & & big farmers & small farmers & \\
\hline Sokya & \multirow[t]{2}{*}{6} & 32,500 & 21,400 & \\
\hline$\left({ }^{\prime} \mathrm{A} \vee \varepsilon \alpha\right)$ & & or: $\quad 60.3 \%$ & or: $39.7 \%$ & $53,900 \mathrm{~h}$ \\
\hline Gâvurköy & \multirow[t]{2}{*}{6} & 37,000 & 4,200 & \\
\hline 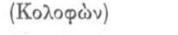 & & or: $90 \% *$ & or: $10 \% *$ & $41,200 \mathrm{~h}$ \\
\hline \multirow{2}{*}{$\begin{array}{l}\text { Çesme } \\
\text { (Kṕńn }\end{array}$} & \multirow[t]{2}{*}{6} & 9,065 & 6,000 & \\
\hline & & or: $\quad 60.2 \%$ & or: $39.8 \%$ & $15,065 \mathrm{~h}$ \\
\hline \multirow{2}{*}{ 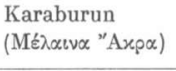 } & \multirow[t]{2}{*}{ - } & \multirow[t]{2}{*}{ —** } & 4,000 & \\
\hline & & & or: $100 \%$ & $4,000 \mathrm{~h}$ \\
\hline \multirow[t]{2}{*}{ TOTAL } & \multirow[t]{2}{*}{18} & 78,565 & 35,6001 & $114,165 \mathrm{~h}$ \\
\hline & & or: $68.8 \%$ & or: $31.2 \%$ & $100 \%$ \\
\hline
\end{tabular}

* The percentages 90 and $10 \%$ are arbitrary: Poulakis iniorms us that only a small number of lands belonged to small farmers.

** There were no large estates in Karaburun because the country was moun a cous.

\section{TABLE 2: POPULATION BY ETHNIG GROUP IN ÇESME PENINSULA}

\begin{tabular}{lrrccc}
\hline Districts & Greeks & Turks & TOTAL & \% Hellenic & \% Turkich \\
\hline Gâvurköy & 1,430 & 904 & $2,33^{\prime}$ * & 61.3 & 38.7 \\
Sokya & $\mathbf{1 2 , 6 2 5}$ & 7,600 & $20,795^{*}$ & 60.7 & 36.5 \\
Karaburun & $\mathbf{6 , 1 5 0}$ & 3,124 & 9,274 & 66.3 & 33.7 \\
Çesme & $\mathbf{4 0 , 5 5 0}$ & 3,440 & $44,120^{* *}$ & 92.0 & 7.7 \\
\hline TOTAL & 60,755 & 15,068 & 76,523 & 79.4 & 19.7 \\
\hline
\end{tabular}

*Figure including: 400 Circassians, 80 Gypsies, 50 Armenians, 40 Ethiopians.

**Figure including: 60 Jews, 40 Ethiopians, 20 gypsies, 10 Armenians.

The $80 \%$ of the population of the above districts were farmers and the $20 \%$ were merchants, building workers, tanners, millers, bankers, fishers, smiths, etc. The agrarian population, according to Poulakis, was 
gradually decreasing in favour of the latter, because the population of these districts were dense, and the existing means of transport did not facilitate the ownership and cultivation of land in the interior (op. cit., p. 100).

If the $80 \%$ of the population (Hellenic and Muslim) professed agriculture and we assume that the land owned by the Hellenic and Turk small farmers was respective to their percentage, we have the following table:

\section{TABLE 3: POPULATION AND LAND OWNERSHIP BY ETHNIC GROUP}

\begin{tabular}{|c|c|c|c|c|}
\hline \multirow{2}{*}{$\begin{array}{l}\text { Districts } \\
\text { Respective \% of } \\
\text { ownership }\end{array}$} & \multicolumn{2}{|c|}{$80 \%$ of } & \multicolumn{2}{|c|}{ Hectares owned: by } \\
\hline & Greeks & Turks & Greeks & Turks \\
\hline $\begin{array}{l}\text { Sokya } \\
\%\end{array}$ & $\begin{array}{l}10,000 \\
62.4 \%\end{array}$ & $\begin{array}{l}6,180 \\
37.6 \%\end{array}$ & 13,354 & 8,046 \\
\hline $\begin{array}{l}\text { Gâvurköy } \\
\text { \% }\end{array}$ & $\begin{array}{l}1,114 \\
61.2 \%\end{array}$ & $\begin{array}{c}723 \\
38.8 \%\end{array}$ & 2,570 & 1,630 \\
\hline $\begin{array}{l}\text { Cesme } \\
\%\end{array}$ & $\begin{array}{l}32,440 \\
92.2 \%\end{array}$ & $\begin{array}{r}2,752 \\
7.8 \%\end{array}$ & 5,532 & 468 \\
\hline $\begin{array}{l}\text { Karaburun } \\
\%\end{array}$ & $\begin{array}{l}4,920 \\
66.3 \%\end{array}$ & $\begin{array}{l}2,499 \\
33.7 \%\end{array}$ & 2,652 & 1,348 \\
\hline \multirow{2}{*}{ TOTALS } & 48,474 & 12,154 & 24.108 & 11.492 \\
\hline & \multicolumn{2}{|c|}{60,628} & \multicolumn{2}{|c|}{35,600} \\
\hline
\end{tabular}

Interpreting this table, we see that the Ottoman Greeks might have been more numerous than the Turks, but only overall the rate of agrarian ownership was in favour of the Turks: 24,108 hectares belonged to 48,604 Greeks (rate 1:2), while 11,942 h. belonged to 12,054 Turks (rate 1:1).

On the other hand, we see that 60.628 farmers, Ottoman Greeks and Turks, i.e. the $79.2 \%$ of the population (including minorities, such as Circassians, Jews, etc.), owned only $35,600 \mathrm{~h}$. namely $31.2 \%$ of the arable land, as against the remaining $68.8 \%$ (78,565 h.) which belonged to only 18 çiftliks.

(Source: Poulakis, op. cit.) 


\section{APPENDIX 2}

TABLE 1: OCCUPATIONAL GROUPS IN CAPPADOCIA, 1924

\begin{tabular}{|c|c|c|c|c|c|c|c|c|c|}
\hline & Professions & $\begin{array}{l}\text { Guélveri } \\
\text { Aleseray) }\end{array}$ & $\begin{array}{l}\text { Caesa- } \\
\text { rea }\end{array}$ & $\begin{array}{l}\text { Neo- } \\
\text { sehir }\end{array}$ & Nidge & $\begin{array}{l}\text { Procopi } \\
\text { (Urkiup) }\end{array}$ & $\begin{array}{l}\text { Pharasa } \\
\text { (Varaso) }\end{array}$ & TOTAL & $\%$ \\
\hline 1 & Bakers & - & - & 10 & 11 & 5 & - & 26 & 0.3 \\
\hline 2 & Farmers & 268 & 604 & 663 & 2,044 & 137 & 483 & 4,199 & 54.5 \\
\hline 3 & Money-lenders & 17 & 4 & 3 & 4 & 2 & - & 30 & 0.4 \\
\hline 4 & 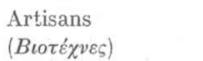 & 8 & 43 & 19 & 3 & 449 & - & 522 & 6.8 \\
\hline 5 & Herdsmen & 2 & 3 & - & 20 & 2 & 5 & 32 & 0.4 \\
\hline 6 & Hawkers & 7 & 5 & 11 & 2 & - & 1 & 26 & 0.3 \\
\hline 7 & Soleicitors & 1 & 1 & 1 & 5 & 1 & - & 9 & 0.1 \\
\hline 8 & Merchants & 41 & 144 & 124 & 197 & 53 & 3 & 362 & 7.3 \\
\hline 9 & Workers & 6 & 23 & 31 & 60 & 26 & 18 & 164 & 2.1 \\
\hline 10 & Teachers & 3 & 24 & 22 & 28 & 19 & - & 96 & 1.2 \\
\hline 11 & Med. doctors & - & 1 & 6 & 8 & 4 & - & 19 & 0.3 \\
\hline 12 & Priests & 2 & 29 & 18 & 28 & 9 & 13 & 99 & 1.3 \\
\hline 13 & $\begin{array}{l}\text { Coffee-house } \\
\text { keepers }\end{array}$ & 4 & 3 & 13 & 19 & 7 & - & 46 & 0.6 \\
\hline 14 & Barbers & - & 11 & 10 & 34 & 7 & - & 62 & 0.8 \\
\hline 15 & Landowners & 5 & 12 & 16 & 47 & 4 & 10 & 94 & 1.2 \\
\hline 16 & Butchers & - & 4 & 12 & 13 & 7 & - & 36 & 0.5 \\
\hline 17 & Cooks (innkeepers) & 4 & 2 & 4 & 22 & 13 & - & 45 & 0.6 \\
\hline 18 & $\begin{array}{l}\text { Carriers } \\
\text { (hetapopeis) }\end{array}$ & 2 & 13 & 20 & 112 & 5 & 5 & 157 & 2.0 \\
\hline 19 & Mechanics & 1 & - & 3 & 2 & - & - & 6 & 0.1 \\
\hline 20 & Grocers (bakkals) & 11 & 27 & 81 & 83 & 52 & 9 & 263 & 3.4 \\
\hline 21 & 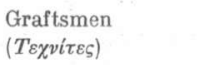 & 61 & 97 & 183 & 181 & 280 & 48 & 850 & 11.0 \\
\hline 22 & Employees & 2 & 9 & 16 & 50 & 16 & - & 93 & 1.2 \\
\hline 23 & Chemists & 1 & 1 & 1 & 5 & 2 & - & 10 & 0.1 \\
\hline 24 & Church Chanters & 1 & 7 & 13 & 18 & 2 & - & 41 & 0.5 \\
\hline 25 & $\begin{array}{l}\text { Various other } \\
\text { professions }\end{array}$ & 4 & 38 & 72 & 74 & 24 & 8 & 220 & 3.0 \\
\hline & TOTAL & 451 & 1,105 & 1,352 & 3,070 & 1,126 & 603 & $7,70 \%$ & 100 \\
\hline
\end{tabular}


The above are the official figures of 1924, registered for the exchange of populations. Twenty four professions are listed for a Hellenic population of 44,075 persons, or 11,293 families. So, each family in Cappadocia consisted of 4 persons. From the 44,075 inhabitants only 7,707 were active, namely the $17,5 \%$.

Farmers were the majority with $54.5 \%$. They were followed by craftsmen $11 \%$, merchants $7.3 \%$, artisans $6.8 \%$, grocers $3.4 \%$ and workers $2.1 \%$. These figures are not absolutely trustworthy because most of the active population professed more than one job. For instance, the $0.4 \%$ of money-lenders does not show their real number. Most merchants, grocers and others along with their outward professions, also lent money (Asvesti, p. 175). The farmers also, mainly those with small properties, increased their poor income by doing something else, usually as workers in primitive asbestos furnaces (ibid., p. 178).

Most of the workers were seasonal workers in agriculture, but also in mills, constructions, mines, etc. As for the carriers, they were travelling merchants or big hawkers who formed caravans with mules, donkeys and camels. They carried and sold goods from one place to another, most often at a big profit (ibid., pp. 187-8). The craftsmen were distinguished from those established in urban centres and their craft was exclusively their profession and from those of the agarian districts, who worked in a craft as a means of increasing their agrarian income. Asvesti includes in the craftsmen, the tailors, shoe-makers, ironsmiths and others, while in the entry «artisans» family-owned looms are included (ibid., p. 195, 197). 


\section{APPENDIX 3}

TABLE 1: OCCUPATIONAL GROUPS IN SMTRNA, 1888

(Source: Yearbook and Guide of Smyrna. . for 1888, op. cit.,p. 293 - 323)

\begin{tabular}{|c|c|c|c|c|}
\hline $\begin{array}{l}\text { Serial } \\
\text { No. }\end{array}$ & Professions & $\begin{array}{l}\text { Ottoman Greeks } \\
\text { (or Greek subjects) }\end{array}$ & $\begin{array}{c}\text { Total } \\
\text { Mentioned }\end{array}$ & $\begin{array}{c}\text { Hellenic } \\
\%\end{array}$ \\
\hline 1 & Printers & $7 / 19$ & & 36.8 \\
\hline 2 & Painters of Holy pictures & $4 / 4$ & & 100.0 \\
\hline 3 & Flour dealers & $19 / 23$ & & 82.6 \\
\hline 4 & Coach owners & $10 / 12$ & & 83.3 \\
\hline 5 & Coach manufacturers & $5 / 5$ & & 100.0 \\
\hline 6 & Coach painters & $3 / 3$ & & 100.0 \\
\hline 7 & 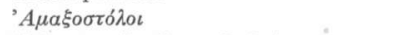 & $2 / 2$ & & 100.0 \\
\hline 8 & Makers and sellers of $a b a^{*}$ & $7 / 10$ & & 20.0 \\
\hline 9 & Dealers of colonial products & $13 / 22$ & & 59.0 \\
\hline 10 & Retailers of " " & $13 / 22$ & & 59.0 \\
\hline 11 & Money lenders & $21 / 33$ & & 63.6 \\
\hline 12 & Bankers & $26 / 30$ & & 86.6 \\
\hline 13 & Architects & $6 / 12$ & & 50.0 \\
\hline 14 & Steam-mills owners & $4 / 10$ & & 40.0 \\
\hline 15 & Book-binders & $9 / 9$ & & 100.0 \\
\hline 16 & Stationery owners & $11 / 18$ & & 61.1 \\
\hline 17 & Tanneries & $4 / 11$ & & 36.3 \\
\hline 18 & Leather shops & $9 / 13$ & & 62.2 \\
\hline 19 & Cereal dealers & $7 / 14$ & & 50.0 \\
\hline 20 & Sculptors & $5 / 5$ & & 100.0 \\
\hline 21 & Solicitors & $37 / 65$ & & 56.9 \\
\hline 22 & Fur dealers & $14 / 14$ & & 100.0 \\
\hline 23 & Dealers of domestic products & $6 / 8$ & & 75.0 \\
\hline 24 & Merchants & $208 / 369$ & & 56.3 \\
\hline 25 & Merchants - retailers & $20 / 20$ & & 100.0 \\
\hline 26 & Proxies & $11 / 37$ & & 29.7 \\
\hline 27 & Furniture (manufacturers and dealers) & $8 / 10$ & & 80.0 \\
\hline 28 & Dyeworks & $\begin{array}{r}10 / 10 \\
(3 \text { of which ares } \\
\text { powered }\end{array}$ & $\begin{array}{l}\text { steam- } \\
\text { d) }\end{array}$ & 100.0 \\
\hline 29 & Woolshops & $15 / 21$ & & 71.4 \\
\hline 30 & Restaurants & $\begin{array}{r}8 / 16 \\
\text { (those with clea } \\
\text { signboards) }\end{array}$ & arly Greek & 50.0 \\
\hline 31 & Ready made cloth shops & $4 / 9$ & & 44.1 \\
\hline 32 & Matress makers & $2 / 9$ & & 22.2 \\
\hline
\end{tabular}

*aba: coarse woolen stuff. 
ON THE ECONOMIC ACTIVITIES ON THE ANATOLIAN GREEKS

\begin{tabular}{|c|c|c|c|c|}
\hline $\begin{array}{l}\text { Serial } \\
\text { No. }\end{array}$ & Professions & $\begin{array}{l}\text { Ottoman Greeks } \\
\text { (or Greek subjects) }\end{array}$ & $\begin{array}{c}\text { Total } \\
\text { Mentioned }\end{array}$ & $\begin{array}{c}\text { Hellenic } \\
\%\end{array}$ \\
\hline 33 & Confectionnery & $21 / 23$ & & 91.3 \\
\hline 34 & Beerhouse & $2 / 4$ & & 50.0 \\
\hline 35 & Brewery & $1 / 1$ & & 100.0 \\
\hline 36 & Painters & $2 / 4$ & & 50.0 \\
\hline 37 & $\Theta \alpha \lambda \alpha \mu \circ \sigma \tau \delta ́ \lambda . \iota$ & $4 / 5$ & & 80.0 \\
\hline 38 & Doctors & $41 / 74$ & & 55.4 \\
\hline 39 & Chair makers & $5 / 5$ & & 100.0 \\
\hline 40 & Packers & $6 / 6$ & & 100.0 \\
\hline 41 & Nail makers & $11 / 12$ & & 91.6 \\
\hline 42 & Coffeeshops (with Greek signboards) & $14 / 33$ & & 42.4 \\
\hline 43 & Wax-chandlers & $5 / 6$ & & 83.3 \\
\hline 44 & Ironmongers & $16 / 21$ & & 76.1 \\
\hline 45 & Jewellers & $4 / 7$ & & 57.1 \\
\hline 46 & Barbershops & $17 / 17$ & & 100.0 \\
\hline 47 & Butchers & $21 / 23$ & & 91.3 \\
\hline 48 & Tinsmiths & $9 / 12$ & & 75.0 \\
\hline 49 & Stone masons & $7 / 7$ & & 100.0 \\
\hline 50 & Macaroni makers & $9 / 9$ & & 100.0 \\
\hline 51 & Agents & $61 / 78$ & & 78.2 \\
\hline 52 & Agents of colonial products & 6911 & & 54.5 \\
\hline 53 & House agents & $5 / 10$ & & 50.0 \\
\hline 54 & Exchanging agents & $8 / 13$ & & 61.5 \\
\hline 55 & Translators & $2 / 2$ & & 100.0 \\
\hline 57 & Silk shops & $3 / 4$ & & 75.0 \\
\hline 58 & Silk manufacturers & $14 / 15$ & & 93.3 \\
\hline 59 & Music teachers & $5 / 21$ & & 23.8 \\
\hline 60 & Musical instrument dealers & $-/ 16$ & & - \\
\hline 61 & Shipping agents & $1 / 4$ & & 25.0 \\
\hline 62 & Marine stores & $7 / 7$ & & 100.0 \\
\hline 63 & Novelties shops & $2 / 8$ & & 25.0 \\
\hline 64 & Yarn shops & $8 / 24$ & & 33.3 \\
\hline 65 & Hotels (with Greek signboards) & $9 / 13$ & & 69.2 \\
\hline 66 & Dry fruit dealers & $7 / 7$ & & 100.0 \\
\hline 67 & Timber merchants & $18 / 27$ & & 66.6 \\
\hline 68 & Wood works & $3 / 5$ & & 60.0 \\
\hline 69 & Wood carvers & $4 / 4$ & & 100.0 \\
\hline 70 & Carpenters & $12 / 13$ & & 92.3 \\
\hline 71 & Dentists & $4 / 7$ & & 57.1 \\
\hline 72 & Wine-industries & $21 / 25$ & & 84.0 \\
\hline 73 & Distilleries (spirit-manufacturers) & $27 / 31$ & & 87.0 \\
\hline 74 & Bronze makers & $6 / 6$ & & 100.0 \\
\hline 75 & Retailers & $9 / 13$ & & 69.2 \\
\hline
\end{tabular}




\begin{tabular}{|c|c|c|c|c|}
\hline $\begin{array}{c}\text { Serial } \\
\text { No. }\end{array}$ & Professions & $\begin{array}{l}\text { Ottoman Greeks } \\
\text { (or Greek subjects) }\end{array}$ & $\begin{array}{l}\text { Total } \\
\text { Mentioned }\end{array}$ & $\begin{array}{c}\text { Hellenic } \\
\%\end{array}$ \\
\hline$\cdots$ & - & $\ldots$ & & \\
\hline 76 & Grocers & $13 / 13$ & & 100.0 \\
\hline $77^{-}$ & Hatters & $6 / 6$ & & 100.0 \\
\hline 78 & Tailors & $17 / 25$ & & 68.0 \\
\hline 79 & Sellers of sewing machines & $2 / 5$ & & 40.0 \\
\hline 80 & Piano tuners & $2 / 4$ & & 50.0 \\
\hline 81 & Sack dealers & $3 / 8$ & & 37.5 \\
\hline 82 & soap factories & $7 / 8$ & & 87.5 \\
\hline 83 & Sesame-oil factories & $9 / 9$ & & 100.0 \\
\hline 84 & - Cigarette paper dealers & $13 / 13$ & & 100.0 \\
\hline 85 & Ironmongers & $6 / 7$ & & 87.5 \\
\hline 86 & Iron industries & $4 / 7$ & & 57.1 \\
\hline 87 & Iron dealers & $5 / 11$ & & 45.5 \\
\hline 88 & Iron works & $15 / 17$ & & 88.2 \\
\hline 89 & Carpet merchants & $-/ 13$ & & - \\
\hline 90 & Bankers & $30 / 49$ & & 68.1 \\
\hline 91 & Purveyors of steamers & $6 / 12$ & & 50.0 \\
\hline 92 & Sellers of çember* & $2 / 6$ & & 33.3 \\
\hline 93 & Hydropathic establishments & $2 / 2$ & & 100.0 \\
\hline 94 & Glassware shops & $9 / 14$ & & 64.2 \\
\hline 95 & Shoe-makers & $17 / 21$ & & 80.9 \\
\hline 96 & Fashion shops & $20 / 24$ & & 83.3 \\
\hline 97 & Draperies & $19 / 31$ & & 61.2 \\
\hline 98 & Photographers & $1 / 6$ & & 16.6 \\
\hline 99 & Machine dealers & $5 / 10$ & & 50.0 \\
\hline 100 & Chemists & $34 / 43$ & & 79.0 \\
\hline $101-$ & Coppersmiths & $8 / 8$ & & 100.0 \\
\hline 102 & Goldsmiths & $27 / 40$ & & 67.5 \\
\hline 103 & Paint-stores & $\therefore 5 / 5$ & & 100.0 \\
\hline 104 & Watch sellers & $8 / 17$ & & 47.0 \\
\hline
\end{tabular}

* fember: neckerchief.

The above table is by no means accurate, as far as the number of professions and entrepreneurs are concerned. Especially the total number of entrepreneurs listed in the Guide seems to be considerably lower than the real one. This may have been due to the fact that the Guide was almost exclusively addressed to the Hellenic (and Greek) element of Smyrna. Thus, the majority of those listed were Greeks. This is quite obvious in several professions, in which only Greeks appear to have a share, or in which the Hellenic share is, for no obvious reason, remarkably high. The order of the professions follows the Greek alphabetical order. 
ON THE ECONOMIC ACTIVITIES OF THE ANATOLIAN GREEKS

\section{APPENDIX 4}

(Source: Demirzakis, Industrial Production of the Aydin Vilayet, op. cit.) TABLE 1: INDUSTRIAL PLANTS IN THE AYDIN VILAYET (1919)

\begin{tabular}{lrrr}
\hline Sancaks & Plants & H.P. & Value in T£ \\
\hline Smyrna & 2,555 & 8,881 & $2,135,940$ \\
Magnisia (Saruhan) & 1,295 & 1,232 & 528,996 \\
Aydin & 413 & 1,462 & 496,950 \\
Denizli & 345 & 557 & 192,400 \\
Mentese & 395 & 189 & $\mathbf{1 1 3 , 1 4 5}$ \\
Ayvalik & 305 & 888 & 387,550 \\
\hline TOTAL & 5,308 & 13,209 & $3,854,980$ \\
\hline
\end{tabular}

Table 1 is based on private statistics. The Sancaks mentioned, Ayvalik included, were under occupation by the Greek Army.

By the term «Plants» were meant industrial units and also workshops. Family-owned looms are also included in the term workshop. That is the reason why figures are high. However, these figures do not take into account nationality. Finally, the value of the T£ seems to be that of 1919.

TABLE 2: INDUSTRIAL PLANTS ACCORDING TO NATIONALITY (1919)

\begin{tabular}{|c|c|c|c|c|c|c|c|}
\hline Nationality & Hellenic & Turkish & Armen. & Jewish & Brit. & French & Austrian \\
\hline Plants & 4,008 & 1,216 & 28 & 21 & 13 & 8 & 6 \\
\hline Workers employed & 28,166 & 5,766 & 363 & 339 & 1,489 & 143 & 101 \\
\hline$\%$ of workers & 75.75 & 15.51 & 0.98 & 0.62 & 4.00 & 0.38 & 0.27 \\
\hline Nationality & Italian & U.S.A. & \multicolumn{2}{|c|}{ German } & Belgian & \multicolumn{2}{|r|}{ TOTAL } \\
\hline Plants & 3 & 2 & \multicolumn{2}{|l|}{2} & 1 & \multicolumn{2}{|r|}{5,308} \\
\hline Workers employeed & 75 & 190 & \multicolumn{2}{|c|}{35} & 528 & \multicolumn{2}{|r|}{37,185} \\
\hline$\%$ workers & 0.20 & 0.78 & \multicolumn{2}{|c|}{0.09} & 1.42 & & 100 \\
\hline
\end{tabular}


TABLE 3: DISTRIBUTION OF LABOUR POWER BY SEX

\begin{tabular}{|c|c|c|c|c|}
\hline & Companies & Men & Women & Total \\
\hline \multirow[t]{12}{*}{ a) } & Limited Companies (S.A.) & & & \\
\hline & Brasserie Bomonti-Nectar & 35 & 5 & 40 \\
\hline & Ottoman Cloth Co. & 256 & 200 & 456 \\
\hline & Cnie de filature et de Tissage & 128 & 300 & 428 \\
\hline & S. A. de Manufacture de Coton & 207 & 300 & 507 \\
\hline & Valex (Fabrique d'extrait de valonnées) & 150 & - & 150 \\
\hline & McAndrews and Forbes & 208 & 60 & 268 \\
\hline & Ottoman Gaz Co. & 215 & 一 & 215 \\
\hline & Sté des Eaıx & 60 & & 60 \\
\hline & The Smyrna Fig Packers & 200 & 60 & 260 \\
\hline & Kassamba and Aydin Railways & $1,500^{1}$ & - & 1,500 \\
\hline & Régie Orromane de tabacs & - & - & $4,000^{2}$ \\
\hline \multirow{6}{*}{$\begin{array}{l}\text { b) } \\
\text { c) } \\
\text { d) }\end{array}$} & Workers in industries and workshops & - & - & $23,666^{3}$ \\
\hline & Workers working for themselves & - & 4,735 & 4,735 \\
\hline & Workers working at home for the Oriental & & & \\
\hline & Carpets Ltd. & 一 & 6,400 & 6,400 \\
\hline & \multirow{2}{*}{ TOTAL } & 2,959 & 12,060 & \multirow[b]{2}{*}{$42,685^{4}$} \\
\hline & & \multicolumn{2}{|c|}{15,019} & \\
\hline
\end{tabular}

$(1,2)$. The workers of the Railways and the Régie have been added to the table by the author. Thus 42,685 minus the 5,500 workers of the Railways and the Régie is 37,185, namely the total given by Demirzakis in table 2. Figure (1) is linked with «men» because of the kind of work, whereas (2) with "total», because the kind of works is unspecified.

(3). This figure is linked with «total» by Demirzakis, and (4) includes the 5,500 workers of the Railways and the Régie. The high number of women was obviously due to the carpet weavers.

TABLE 4: HELLENIC AND TURKISH INDUSTRIES FOUNDED FROM 1891 UNTIL 1919, IN THE AYDIN VILAYET

\begin{tabular}{|c|c|c|c|c|c|c|c|c|}
\hline$\frac{\text { Sancaks }}{\text { Date }}$ & Smyrna & $\begin{array}{c}\text { Magnis- } \\
\text { sia }\end{array}$ & Aydin & $\begin{array}{c}\text { Deniz- } \\
\quad \boldsymbol{l} i\end{array}$ & $\begin{array}{l}\text { Men- } \\
\text { tesse }\end{array}$ & Ayoalik & Nationality & Total \\
\hline $1891-1900$ & $239 / 43$ & $77 / 25$ & $35 / 13$ & $6 / 1$ & $37 / 16$ & $49 /-$ & Hellenic/Turkish & h $443 / 98$ \\
\hline 1901-1910 & $241 / 17$ & $85 / 10$ & $18 / 8$ & $7 / 2$ & $39 / 11$ & $47 / 2$ & & $437 / 50$ \\
\hline 1911-1919 & $91 / 22$ & $46 / 10$ & $22 / 16$ & $5 / 2$ & $4 / 3$ & $26 /-$ & & $194 / 53$ \\
\hline TOTAL & $571 / 82$ & $208 / 45$ & $75 / 37$ & $18 / 5$ & $80 / 30$ & $122 / 2$ & & $1074 / 201$ \\
\hline
\end{tabular}

